Pamiętnik Literacki 2020, 2, s. 227-258

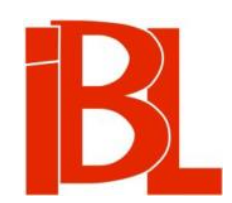

\title{
Wiersze na ryciny jako dominanta polskojęzycznej twórczości Symeona z Połocka. Część 2: Czworaki
}

Radosław Grześkowiak 
Pamiętnik Literacki CXI, 2020, z. 2, PL ISSN 0031-0514

DOI: $10.18318 / \mathrm{pl} .2020 .2 .18$

RADOSŁAW GRZEŚKOWIAK Uniwersytet Gdański

\title{
WIERSZE NA RYCINY JAKO DOMINANTA POLSKOJEZYCZNEJ TWÓRCZOŚCI SYMEONA Z POŁOCKA
}

\author{
CZEŚĆ 2: CZWORAKI*
}

\section{Cztery świata wieki a cykl rycin Quatuor mundi aetates Tobiasa Verhaechta sprzed 1599 roku}

W Pracach i dniach (w. 109-201) Hezjod wyróżnił pięć okresów dziejowych, z których każdy następny oznaczał kolejny stopień degradacji harmonii człowieka i przyrody, jaka panowała na początku: wiek złoty, srebrny, brązowy, bohaterski i żelazny. Sugestywnie przedstawiona koncepcja historiozoficzna upowszechniła się w kształcie nadanym jej przez Owidiusza, który w Metamorfozach (I, w. 89-150) dzieje ludzkości ujął w postaci czterech okresów, pomijając bohaterski ${ }^{1}$.

Wersję tę w renesansie i baroku spospolitowały niezliczone repetycje tekstów literackich ${ }^{2}$. Również w grafice wyobrażenia czterech wieków ludzkości cieszyły się dużym powodzeniem. Dość przypomnieć, że poświęcony im tetraptyk sztychowali m.in. Philips Galle w 1573, Hendrick Goltzius w 1589, Agostino Carracci między 1589 a 1595, Crispijn van de Passe Starszy w 1604, Antonio Tempesta w 1606, Johann Theodor de Bry w 1608 czy Adriaen Matham w 1620 roku, a jest to tylko drobna część miedziorytniczych ilustracji tego tematu. Literaci charakterystykę czterech okresów zazwyczaj wzorowali na znanych opisach Owidiusza, jak choćby Marcin Paszkowski w czterech wierszach zbioru Wykład bogin słowieńskich wesotego widzenia Słońca z Panna $w$ złotym kole nad Krakowem roku Pańskiego 1608, maja dnia $30^{3}$. Przy czym inspiracja dla poetów tworzących w językach wernakularnych bywały również opatrzone łacińskimi inskrypcjami cykle graficzne, jak w przypadku epigramatycznego tetraptyku Wespazjana Kochowskiego Na obrazy

* Pierwsza część artykułu została opublikowana w „Pamiętniku Literackim” 2017, z. 3. (numeracja cząstek jest wspólna). Tam też (przypisy 6 i 8) rozwiązanie skrótów odsyłających do rękopiśmiennych przekazów poezji Symeona z Połocka (oznaczanych numerami rękopisów) oraz do ich współczesnych edycji (sygnalizowanych datami wydania).

1 Zob. np. H. Levi in, Mit wieku złotego - prehistoria. Przeł. M. Ad a m c zy k. „Pamiętnik Literacki” 1982, z. 3/4.

2 Zob. H. Lev in, The Myth of The Golden Age in the Renaissance. Bloomington 1969. - D. Śn i e $\dot{z}-$ k o, Mit wieku złotego $w$ literaturze polskiego renesansu. Wzory, warianty, zastosowania. Warszawa 1996.

3 M. Pa s zkow ski, Utwory okolicznościowe. Oprac. M. Ku r a n, przy współudz. R. Kr zyw e go. T. 1. Warszawa 2017, s. 129-147, III 4-7. 
czterech wieków napisy ${ }^{4}$. Podobna genezę miał również cykl Symeona z Połocka (Samuiła Piotrowskiego-Sitnianowicza):

CZTERY ŚWIATA WIEKI

1. WIEK ZŁOTY

Póki Saturnus miał w swej niebo sprawie, Wszelkie złe ziemi przykrywał łaskawie.

Świat na początku pełen był radości, Pokoja, zgody, pełen życzliwości, Miecza nie znano, ziemia matką była, Bo wszelką żyzność bez prace rodziła.

\section{WIEK SREBRNY}

A gdy Saturna strącił Jowisz z nieba, Rękoma trzeba dorabiać się chleba. Za jego rządu czasy się mieniają, Pożytków ludzie lemieszem szukają.

3. WIEK MIEDZIANY

Miedzianym trzeci wiek słusznie nazwany, Bo świat owszeki w nim jest zepsowany: Ten wiek nauczył nautę morskie wody Płynać z odwagą dla bogactw wygody, Ten wiek rozmierzył włóki i krwawego Marsa zajętrzył do boju srogiego.

4. WIEK ŻELAZNY

Dobrze wiek czwarty zowie się żelazny, Bo się w nim złości wszytkie wynalazły: Wszędy Mars burzy i ognie zapala, Niecnota cnotę, złość dobroć obala. Nie ma-ż już prawdy, nie ma-ż pobożności, Łakomstwo, zdrady, gwałt został i złości ${ }^{5}$.

Cztery świata wieki są spolszczeniem epigramatycznych inskrypcji serii rycin, które przed 1599 rokiem sztychował Jan Collaert Młodszy według projektu wziętego flamandzkiego pejzażysty Tobiasa Verhaechta ${ }^{6}$. Autor dołączonych do nich 6-wersów podpisany został pod ostatnim jako „Laur. Beyerlinck c.”. Młody Laurentius Beyerlinck (końcowe „c.” w podpisie może oznaczać kleryka, święcenia kapłańskie uzyskał on bowiem w 1602 roku), późniejszy wykładowca filozofii i teologii, o zacięciu encyklopedysty (jego dziełem życia było wydane pośmiertnie 7-tomowe kompendium Magnum theatrum vitae humanae, które skądinąd Symeon Połocki

W. Ko c how s ki, Niepróżnujace próżnowanie ojczystym rymem. Kraków 1674. T. 2: Epigrammata polskie, po naszemu fraszki, s. 90-91, II 51-54.

5 Tekst cyklu za przekazem: rkps 1800, k. 119v (por. edycje: 1990, s. 113-114; 2000, s. 184-185; 2014, s. 25).

6 Rosyjscy wydawcy mylnie zakładali, iż poeta wzorował cykl na bliżej przez nich nie określonym utworze Kochanowskiego lub Sarbiewskiego (zob. 1990, s. 404; 2014, s. 296). Ich konstatację podtrzymała B. Ko zak („Arytmologie polskie” Symeona z Połocka. „Opuscula Polonica et Russica” 1999, nr 4, s. 15): „Wydaje się, że autorzy Antologii mińskiej słusznie sugerują, że wzór takiego wiersza mógł zaczerpnać Symeon od któregoś z polsko-łacińskich poetów, np. Jana Kochanowskiego lub Macieja Kazimierza Sarbiewskiego". 
miał w swej bibliotece) ${ }^{7}$, inskrypcje wzorował na ustępach Metamorfoz, nadając im wyraźnie centoniczny charakter - przykładowo, wstępny dystych pierwszego epigramatu został przejęty $z$ innego dzieła Owidiusza (Amores III 8, w. 35-36), a incipit ostatniego z Wergiliusza (Georgica II, w. 341).

Pierwszym wydawca cyklu był Philips Galle, kolejnym jego syn Theodoor, następnie wnuk Philipsa, Jan, który prasował miedzioryty w 1638 roku $^{8}$. Dopiero ten ostatni nadał tetraptykowi tytuł Quatuor mundi aetates i to $\mathrm{z}$ jego edycji korzystał wileński student, pisząc cykl Cztery świata wieki.

Rycina pt. Aetas aurea (Złoty wiek), przedstawiająca grupki nagich osób spożywających owoce i spokojnie bytujących wśród zwierząt, podpisana została inskrypcja:

$$
\begin{aligned}
& \text { Postquam regna senex coeli Saturnus haberet, } \\
& \text { Omne malum tenebris alta tegebat humus. } \\
& \text { Et secura novo florebant gaudia mundo, } \\
& \text { Paxque coronatis vecta regebat equis. } \\
& \text { Non clypeus, nos ensis erat sine vomere tellus } \\
& \text { Obvia foecundos pandit amica sinus. }
\end{aligned}
$$

Ilustracja zatytułowana Aetas argentea (Srebrny wiek), ze zgromadzonymi na pierwszym planie narzędziami rolniczymi, ukazuje trud uprawy roli i prac gospodarskich w górzystym terenie. Towarzyszy jej podpis (il. 1):

$$
\begin{gathered}
\text { Ast ubi Saturnus tenebrosa in Tartara missus, } \\
\text { Totus et invicto sub Iove mundus erat, } \\
\text { Lubrica tum vicibus succedunt tempora certis. } \\
\text { Et gemit attrito vomere durus ager. } \\
\text { Candida mortales scrutantur viscera terrae; } \\
\text { Rimantes varias caeca per antra domos. }
\end{gathered}
$$

Kolejna rycina, zgodnie $\mathrm{z}$ tytułem Aetas aenea mająca przedstawiać wiek miedziany, na pierwszym planie eksponuje różne rodzaje broni, na drugim geometrę ustalającego granice ziemskich posiadłości, w tle zaś okręty na morzu. Charakterystyce tego okresu Owidiusz poświęcił niespełna trzy wersy (Metamorphoses I, w. 125-127), więc zarówno Beyerlinck, komponując inskrypcję, jak i Verhaecht, projektując ilustrująca ją scenę, z konieczności posiłkowali się elementami opisu wieku żelaznego, w którym Owidiusz wspomniał i dzielących grunty mierników, i reprezentujących ludzką chciwość żeglarzy:

\footnotetext{
Terita succedit soboles cui nomen ab aere, Tempora quae secum deteriora tulit.

Hic vagus horrisono credens se navita ponto. Mercibus intactam pauperat arabiam.
}

7 Zob. A. Hip pis ley, E. Lu k'j a n ov a, Simeon Polockij's Library: A Catalogue. Köln 2005, s. 31.

8 W roku 1599 cykl Collaerta zainspirował florenckiego sztycharza A. Tempestę, który swój tetraptyk prasował w rzymskiej oficynie N. van Aelsta. Inskrypcje Beyerlincka powtórzył bez zmian, natomiast scenki obrazujące poszczególne wieki ludzkości wymienił na własne kompozycje, luźno wzorowane na pomysłach Verhaechta. Zob. R. Ra c e, Antonio Tempesta, „The Four Ages of the World”. W zb.: C. M. Fritz, From Artist to Audience: Italian Drawings and Prints from the 15th through 18th Centuries. Works from the Darlene K. Morris Collection. Carlisle 2016 (autorka hasła katalogowego nie rozpoznała antwerpskiego wzorca rycin Tempesty). 


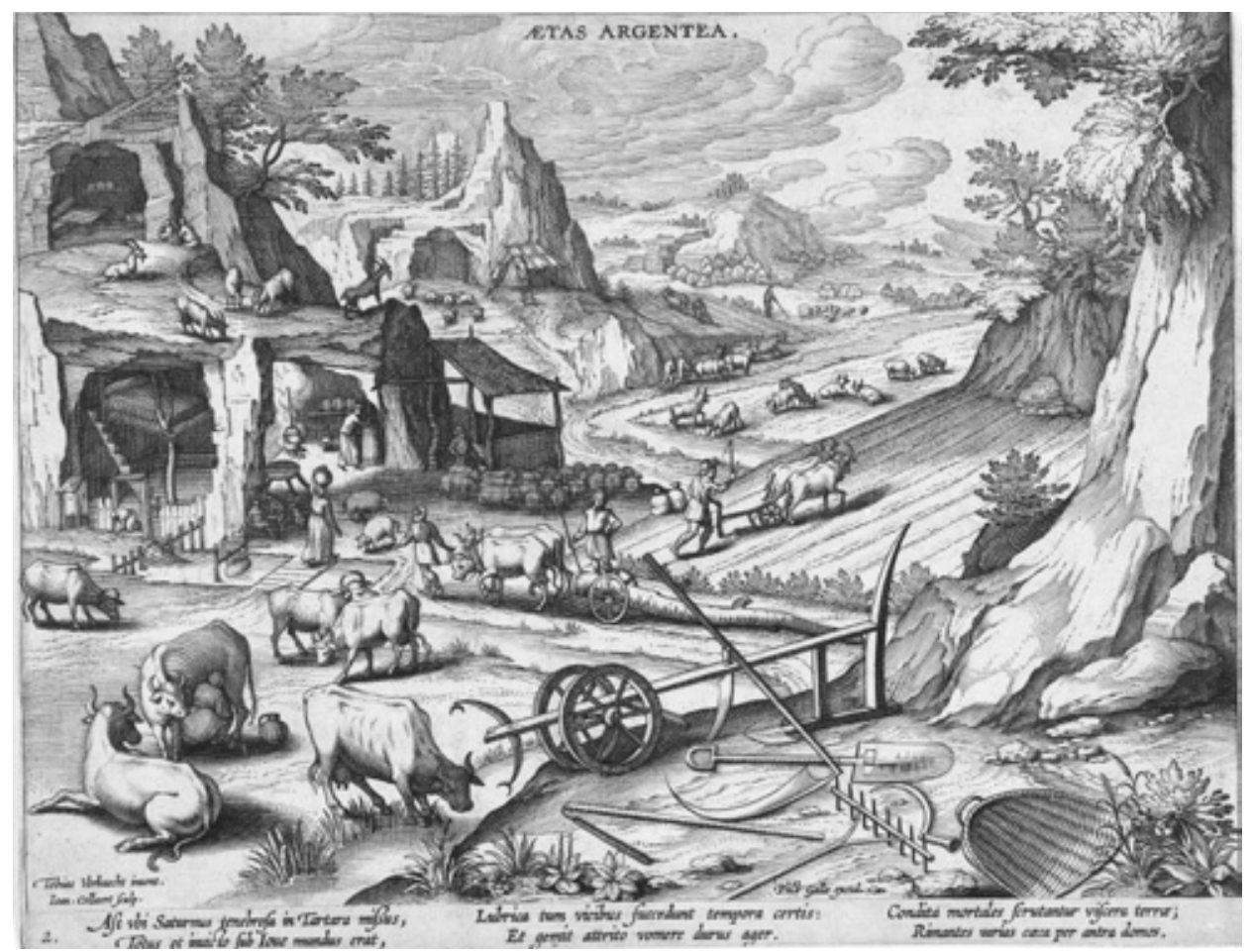

1. Wiek srebrny z cyklu Quatuor mundi aetates, proj. T. Verhaecht, ryt. J. Collaert Młodszy, przed 1599 (pierwodruk, egz. Rijksprentenkabinet, Amsterdam)

Signat humum trepidus sublongo limite mensor, Sanguineusque urget pectora Martis amor.

Ostatnia ilustracja, Aetas ferrea (Żelazny wiek), przedstawiająca na tle pożaru rabunki i gwałty dokonywane przez żołnierzy, podpisana została (il. 2):

Ferrea progenies duris caput extulit antris, Invehit haec mundo protinus omne nefas.

Horrida per cunctas errant incendia terras, Et ferus admissis Mars agitatur equis.

Victa iacet pietas, virtus, rectique decorum, Mox subeunt fraudes, vis, scelus, ardor opum ${ }^{9}$.

Jeśli nie liczyć kilku skrótów myślowych i pominięcia dystychu drugiej inskrypcji, w którym za Owidiuszem mowa jest o tym, iż wobec nastania pór roku ludzie musieli szukać schronienia w jaskiniach, epigramaty Piotrowskiego-Sitnianowicza uznać można za wcale wierne spolszczenia. W przypadku tego cyklu nie interesowały go scenki ukazane na ilustracjach, lecz wyłącznie translacje poetyckich podpisów Beyerlincka.

9 Zob. The Collaert Dynasty. Comp. A. Diels, M. Leeserg. Ed. M. Leeserg, A. Balis. Rotterdam 2005. Cz. 6, s. 40-43, nry 1318-1321. 


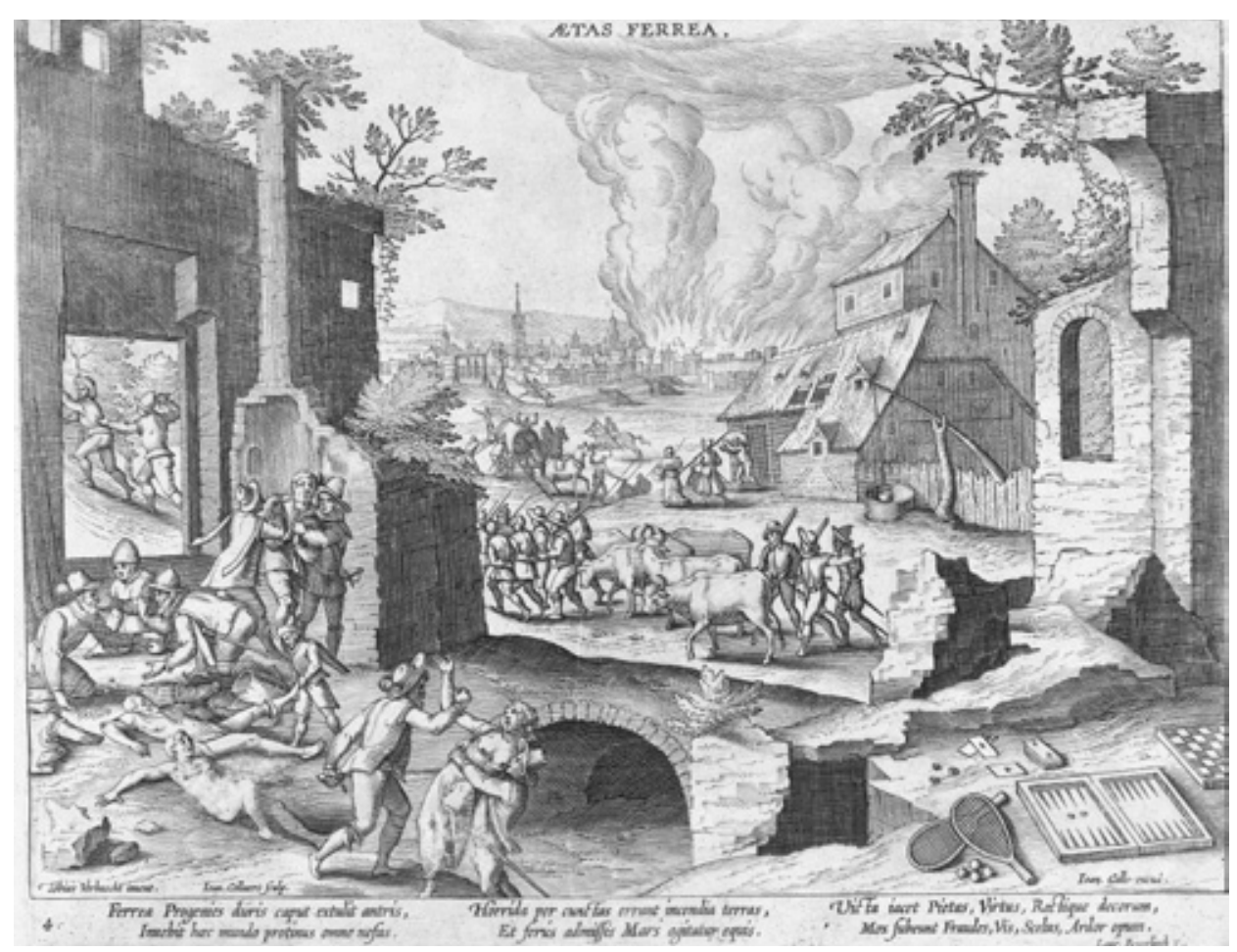

2. Wiek żelazny z cyklu Quatuor mundi aetates, proj. T. Verhaecht, ryt. J. Collaert Młodszy, przed 1599 (wyd. 3, egz. Rijksprentenkabinet, Amsterdam)

\section{Czterech części roku pogody a cykl rycin Quatuor anni tempestates Maartena van Heemskercka z 1563 roku}

Również temat czterech pór roku w grafice XVI i XVII wieku cieszył się sporym powodzeniem, czego wypadkową było duże zróżnicowanie sposobów jego ujęcia. Początkowo popularne były tryumfy alegorycznych postaci wiosny, lata, jesieni i zimy, znane choćby z cykli Georga Pencza (ok. 1531), Virgila Solisa (przed 1537), Jana van der Straeta (ok. 1560) czy dwóch serii Antonia Tempesty (1592). Ich pomysłodawcy, dobierając atrybuty personifikacji, na ogół inspirowali się zdawkową deskrypcją Owidiusza (Metamorphoses II, w. 27-30):

\footnotetext{
Stała i nowa Wiosna, skroni przystrojone

Mając kwitnącym wieńcem, tuż i Lato stało

Nagie, kłosiany wieniec na głowie swej miało,

I Jesień jagodami brudna deptanymi,

I zmarzła Zima włosmi porosła siwymi ${ }^{10}$.
}

10 P. Owidius Na s o, Księgi Metamorphoseon, tojest Przemian. Przeł. W. O tw in ow s ki. Kraków 1638, s. 49. Opis ten - bezpośrednio lub za pośrednictwem przedstawień graficznych - oddziaływał również na sposób ukazania pór roku w dawnej polskiej poezji. Zob. np. fragmenty: „Lato [...] nadchodzi, / [...] kłosianym wieńcem swe rozkwitłe skronie / obtoczywszy”, i: „Ona [tj. Zima] swe http://rcin.org.pl 
Niektórzy graficy posługiwali się zestawem mitycznych personifikacji pór roku. Kilka cykli zainspirowały ilustracje wydanego w 1499 druku Francesca Colonny Hypnerotomachia Poliphili, na których wiosnę uosabiała Wenus z Kupidem, lato Ceres $\mathrm{z}$ rogiem obfitości, jesień Bachus, zimę zaś bóg wiatrów Eol ${ }^{11}$. Pomysł ów wyzyskali m.in. Lambert Lombard w 1568 oraz Maarten de Vos w dwóch różnych seriach: pierwszej rytowanej przez Adriaena Collaerta około 1587 roku, drugiej zaś - przez Crispijna van de Passego Starszego ${ }^{12}$.

$\mathrm{Z}$ odmiennego pomysłu skorzystał Maarten van Heemskerck, w 1562 roku projektując cykl graficzny poświęcony temu tematowi ${ }^{13}$. W Metamorfozach (XV, w. 199-213) Owidiusz spopularyzował również koncepcję Pitagorasa, wedle której poszczególne pory roku korespondują z czterema etapami życia człowieka:

\author{
Czemuż byście i tego uważać nie mieli, \\ Że się na cztery części i rok każdy dzieli, \\ Podobieństwo naszego wieku kształtujący? \\ Bo młody i dopiero jakby mleko ssący \\ I barzo dziecińskiemu podobny wiekowi \\ Bywać zwykł zawsze, kiedy wiosna się odnowi. \\ [. . . . . . . . . . . . . . . . . . . . . .] \\ Po wiośnie potężniejszy rok w lato przechadza \\ I jakby się w dużego młodzieńca już wradza, \\ Bo nad ten wiek ni żaden w moc może być więtszy, \\ Ani mnożniejszy, ani do płodu gorętszy. \\ A po młodzieńskiej znowu czerstwości odprawie
}

rozpuściwszy srebronitne włosy, / białymi przyodziała jędrzną ziemię kosy" (H. Morsztyn, Światowa Rozkosz 16, w. 93-94, 141-142. W: Wybór poezji. Wstęp, oprac. R. G rześk owiak. Wrocław 2016, s. 280, 284. BN I 326), czy: „[Lato] kłosiany wieniec nosi”, i: „[Jesień] bluszczowy wieniec nosi winem przepleciony" (W. Pot ocki, Tydzień stworzenia świata, w. 245, 257. W: J. T. Trembecki, Wirydarz poetycki. Lwowska Narodowa Naukowa Biblioteka Ukrainy im. W. Stefanyka, Zbiór Ossolińskich, rkps sygn. 5888/I, s. 791).

11 Inspiracją do nich był 4-wiersz przypisywany Euphorbiusowi (incipit: „Vere Venus gaudet florentibus aurea sertis"), spopularyzowany przez zbiór Anthologia Latina (V 55).

12 Zob. np. B. Maurmann-Brond er, Tempora significant. Zur Allegorese der vier Jahreszeiten. W zb.: Verbum et signum. Friedrich Ohly zum 60. Geburtstag überreicht, 10. Januar 1974. Hrsg. H. From m, W. Harms, U. Roberg. T. 1: Beiträge zur mediävistischen Bedeutungsforschung. München 1975. - Vier jaargetijden in de kunst van de Nederlanden 1500-1750. Ed. Y. Bruijnen, P. Huys J an s sen. Zwolle 2003. - Ch. La u ter ba ch, Masked Allegory: The Cycle of the Four Seasons by Hendrick Goltzius, 1594-95. „Simiolus” 2004/05, nr 4. - I. M. Ve ldm a n, Images for the Eye and Soul: Function and Meaning in Netherlandish Prints (1450-1650). Transl. M. Hoyle. Leiden 2006, s. 193-202.

13 Zachowały się datowane na 1562 r. szkice Heemskercka do dwóch rycin cyklu, przedstawiających wiosnę (Fondation Custodia w Paryżu, Collection F. Lugt, nr inw. 1773; zob. K. G. B o on, The Netherlandish and German Drawings of the XVth and XVIth Centuries of the Frits Lugt Collection. Paris 1992: nr 122) oraz lato (Galeria Uffizi we Florencji, nr inw. 2316F; zob. W. Th. Kloek, Beknopte catalogus van de nederlandse tekeningen in het prentenkabinet van de Uffizi te Florence. Utrecht 1975: nr 139). Zob. I. M. Veld m a n, Seasons, Planets and Temperaments in the Work of Maarten van Heemskerck. Cosmo-astrological Allegory in Sixteenth-Century Netherlandish Prints. "Simiolus” 1980, nr 3/4, s. 149, przypis 3. - Maarten van Heemskerck. Comp. I. M. V eld m a n. Ed. G. Luij t e n. T. 2: New Testament, Allegories, Mythology, History and Miscellaneous Subjects. Roosendaal 1994, s. 214. 
Następuje zaś Jesień, w jejże tropy prawie, Już dojźrzała i cicha, która w równej mierze Pół na tę, pół na owę stronę wieku bierze, I podzielając młodość z starością śrzedzizną ${ }^{14}$, Poprzytrząsane nosi skroni swe siwizną. A potym drżącym krokiem starością strudzona Przychodzi Zima albo z włosów obnażona, Albo jeśli ma jakie, tedy wybielałe ${ }^{15}$.

Zgodnie $\mathrm{z}$ tą ideą personifikacje pór roku miewały analogicznie zróżnicowany wiek $^{16}$. Tak samo jest na rycinach zaprojektowanych przez Heemskercka, które po raz pierwszy zostały odbite w 1563 roku (daty wyryto na sztychach ukazujących wiosnę i jesień - w drugim wydaniu, jako nieaktualne, zostały one zatarte) ${ }^{17}$. Oprócz inwentora na miedziorytach zapisano personalia sztycharza i najpewniej też pierwszego wydawcy cyklu, Philipsa Gallego. Po raz kolejny w 1638 roku prasował je Jan Galle, nadając wówczas tytuły poszczególnym rycinom: Ver, Aestas, Autumnus i Hyems, a na pierwszej dopisując również nagłówek serii: Quatuor anni tempestates (Aura czterech pór roku). Autorem 4-wersowych inskrypcji, sygnowanym pod pierwszą z nich skrótem: „Had. Iun.”, był blisko współpracujący $\mathrm{z}$ Heemskerckiem nowołaciński poeta Hadrianus Junius ${ }^{18}$. Cykl jego epigramatów zatytułowany In quatuor anni partes pictura expressas (Na przedstawione na rycinach cztery pory roku) przedrukowany został w ramach zbioru inskrypcji do różnych serii graficznych Pinaces. Lib[er] unus (Księga rycin) w pośmiertnej edycji poety $z$ roku $1598^{19}$.

Wiosnę przedstawił Heemskerck w postaci młodzieńca z łukiem i sokołem. W tle ukazującym bujną wiosenna przyrodę wyróżniają się grupa mężczyzn wbijających tyczki do podparcia winnej latorośli oraz mleczarka dojąca krowę. Na te zajęcia zwracała uwagę inskrypcja Juniusa (il. 3):

\section{Fronde comans, nudusque genu, pharetraque decorus, Procinctuque agilis iuvenis, nisoque superbus, Veris hic est habitus. Fervent geniusque laborque. Lacte fluunt mulctrae, vitemque statumina vallant.}

Na drugiej rycinie lato przestawione zostało jako silnie zbudowany półnagi mężczyzna w wieńcu z kłosów i z pękiem zboża w prawym ręku. Za nim żniwiarze koszą łany na polu, po jego lewej stronie zaś dwie kobiety zajęte są strzyżeniem owiec (il. 4):

podzielając młodość z starością śrzedzizna - tj. pośrednicząc między młodością a starością.

Ovidius Naso, op. cit., s. 613-614.

Zob. np. C. Ripa, Ikonologia. Przeł. I. Kania. Kraków 1998, s. 330-333.

Zob. Veldma n, Seasons, Planets and Temperaments in the Work of Maarten van Heemskerck, s. 149-155.

Zob. I. M. V eld m a n, A Painter and a Humanist: Heemskerck and Hadrianus Junius. W: Maarten van Heemskerck and Dutch Humanism in the Sixteenth Century. Amsterdam 1977.

H. J u n i u s, Poematum liber primus, continens pia et moralia carmina, quorum indicem post encomiastica carmina reperies. Lugduni 1598, s. 157-158 (inskrypcje zostały tu wydane $z$ dwiema odmianami: 1, w. 3 zamiast: „Veris hic est habitus”, jest: „Hic habitus veris”; 4, w. 1 zamiast: „Effoeti mentire senis speciem”, jest: „Mentiris speciem effoeti senis”). 


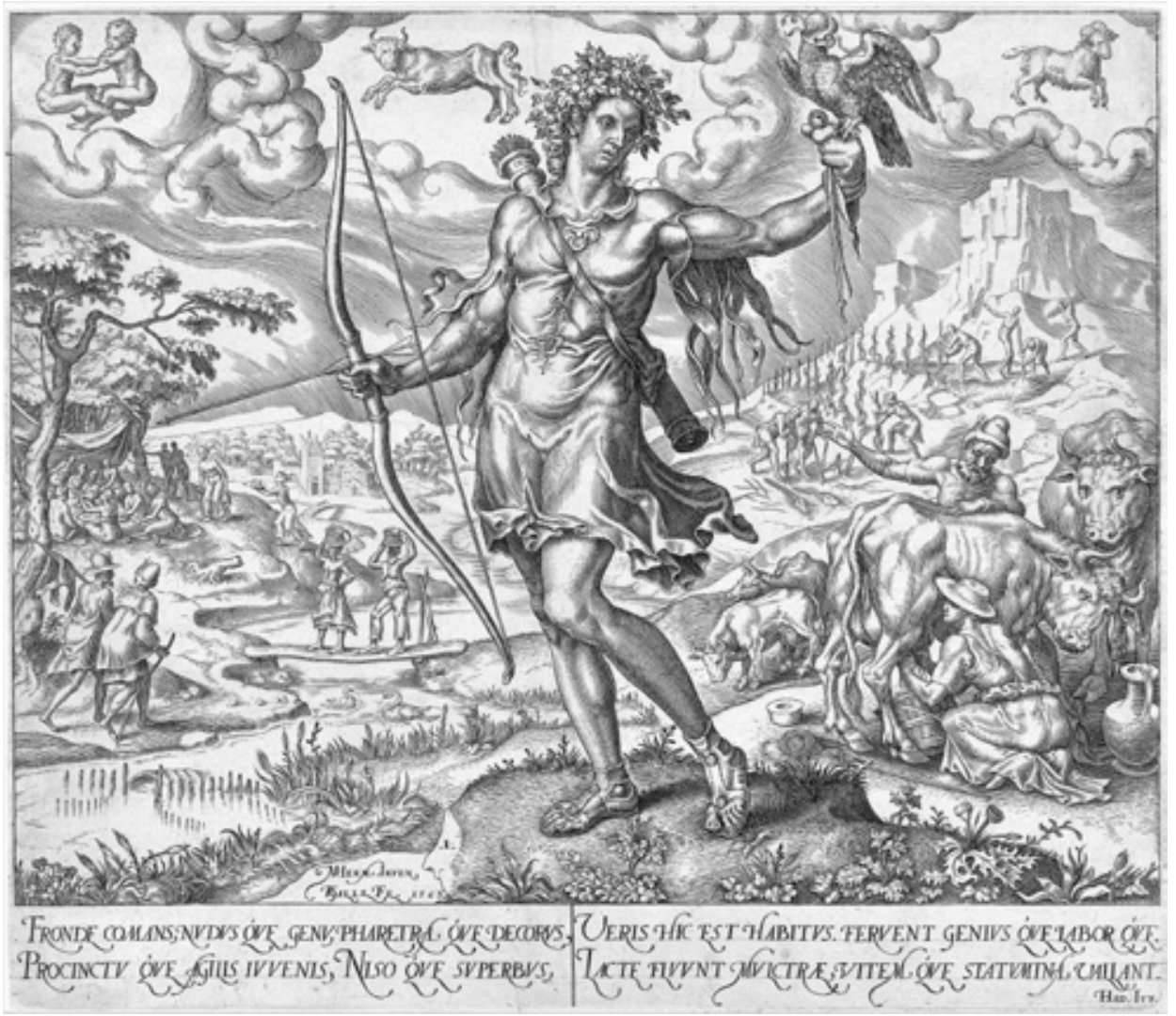

3. Wiosna z cyklu Quatuor anni tempestates, proj. M. van Heemskerck, ryt. Ph. Galle, 1563 (pierwodruk, egz. Rijksprentenkabinet, Amsterdam)

Spicea serta gerens Aestas nuda astat, adulti Ora viri referens, gravidas tendentis aristas. Falce cadunt segetes, tondentur gramine campi. Corniger atque aries lanae deponit honorem.

Dojrzałe w lata uosobienie jesieni trzyma róg obfitości, a za plecami postaci odbywają się m.in. winobranie, orka oraz siew, który - zgodnie z wykładnią Juniusa - daje nadzieję przyszłorocznych zbiorów:

At tu pampineis redimite, Autumne, racemis,

Foecundoque super rerum ditissime cornu,

Quas non fundis opes? Fers musta et roscida poma,

Spemque anni sulcis cerealia semina mandas.

Tło ostatniej ryciny stanowi pejzaż miejski, ukazujacy z jednej strony ślizgawkę na zamarzniętym kanale Haarlemu, z drugiej zaś dwie grupy domowników: część ucztuje, pozostali siedzą przy ciepłym kominku. Na pierwszym planie zaprezento- 


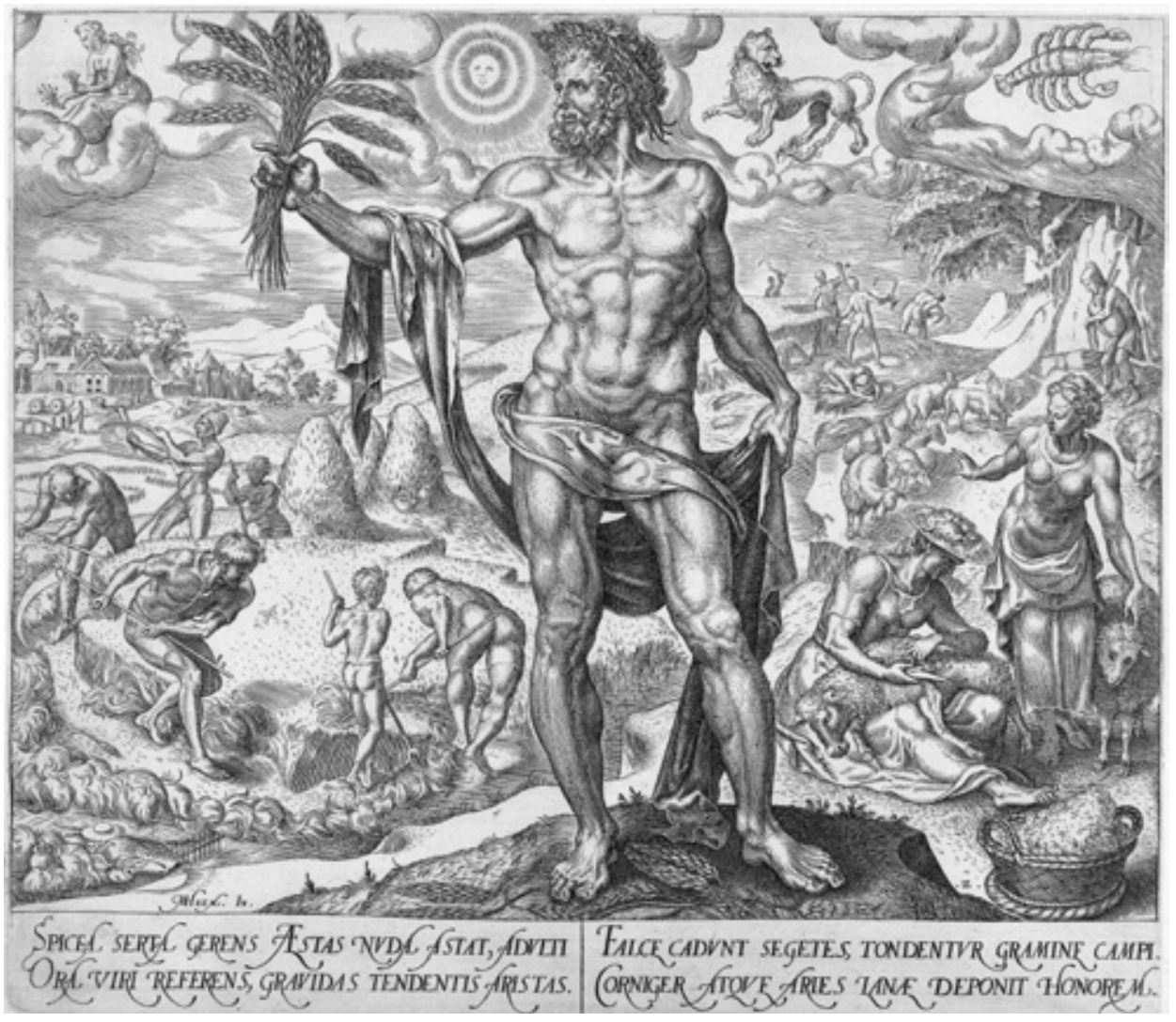

4. Lato z cyklu Quatuor anni tempestates, proj. M. van Heemskerck, ryt. Ph. Galle, 1563 (egz. Rijksprentenkabinet, Amsterdam)

wany został przygarbiony starzec w grubym płaszczu i futrzanej czapce, ogrzewający swe dłonie o garnek $\mathrm{z}$ żarem (il. 5) ${ }^{20}$ :

Effoeti mentire senis speciem algida Bruma.

Hispida barba riget; pellitus tempora cudo,

Corpus abolla duplex operit, plantasque calones.

Exanguesque manus foculus fovet igne coruscus ${ }^{21}$.

20 Eksponowanie ognia w przedstawieniach zimy w ramach cykli obrazujących cztery pory roku i w towarzyszących im inskrypcjach było nie tylko pochodną życiowej empirii, ale również aluzją do innego ustępu Owidiusza (Remedia amoris, w. 187-188), w którym wiośnie przypisał on kwiaty, latu żniwa, jesieni owoce, zimie zaś łagodzący jej srogość ogień.

21 Zob. Veld man, Seasons, Planets and Temperaments in the Work of Maarten van Heemskerck, s. 149-155; Maarten van Heemskerck, s. 214-217, nry 538-541. Na pomyśle rycin Heemskercka wzorował postaci - zwłaszcza personifikacje lata i zimy - H. Goltzius, projektując swój pierwszy cykl poświęcony porom roku, który w 1589 r. sztychował J. Matham. Zob. Veldman, Seasons, Planets and Temperaments in the Work of Maarten van Heemskerck, s. 155. 


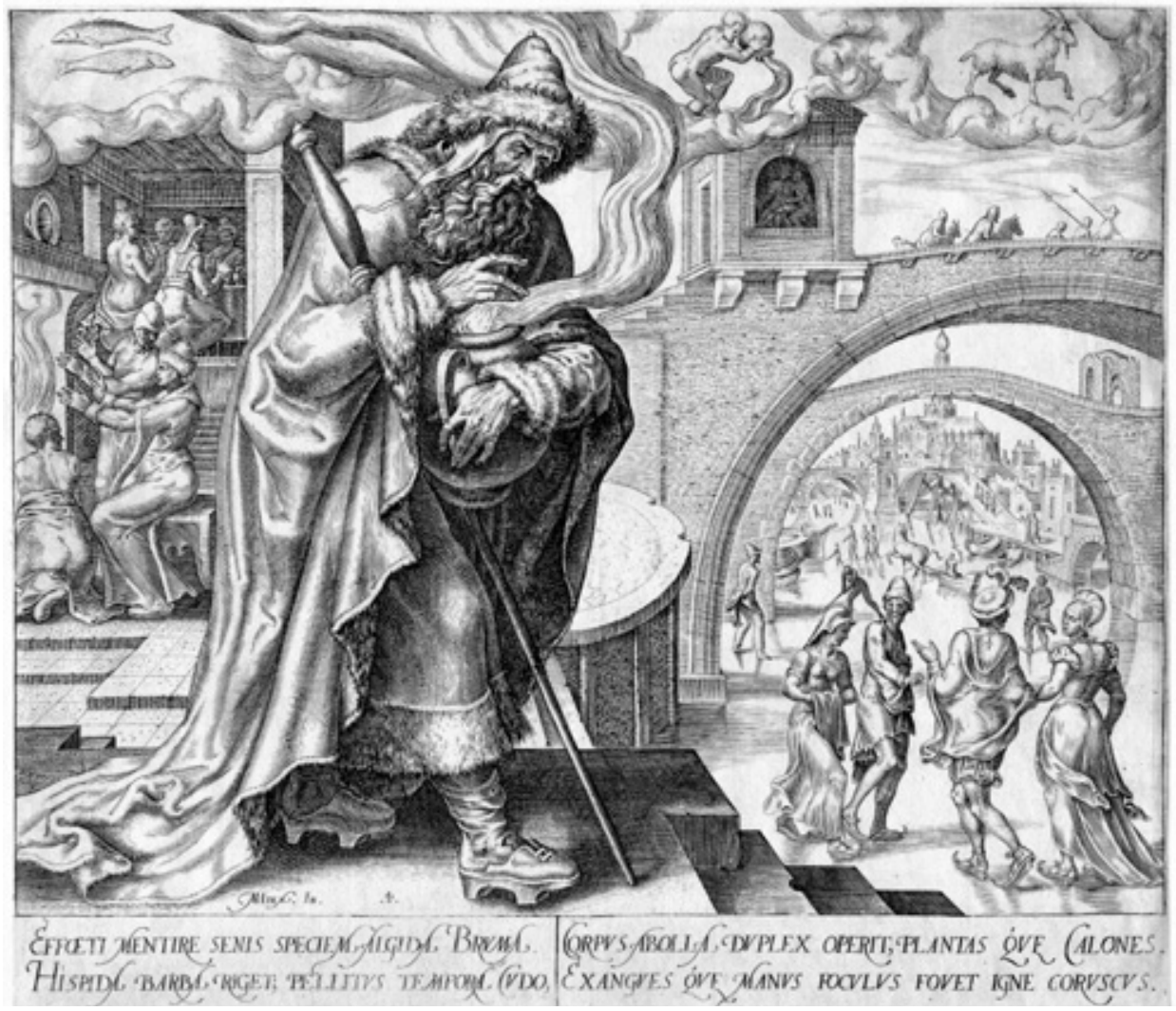

5. Zima z cyklu Quatuor anni tempestates, proj. M. van Heemskerck, ryt. Ph. Galle, 1563 (egz. Rijksprentenkabinet, Amsterdam)

Tytuł, jaki młody poeta $z$ Połocka nadał swemu spolszczeniu, dowodzi, iż korzystał on $\mathrm{z}$ drugiego wydania serii, z 1638 roku:

\section{CZTERECH CZEŚSI ROKU POGODY}

[1]

Młodzian wesoły $\mathrm{z}$ kolan obnażony, Ptak na ręce, łuk w drugiej nałożony Obraz jest wiosny, w którą człek roboczy W winnicy robi, krowa mleko toczy.

[2]

Mąż obnażony z bujnemi kłosami Lato wyraża, w które przed kosami Trawa się ściele i przed sierpem kłosy, Przed nożycami owca traci włosy.

[3]

Szczęśliwa Jesień ma róg obfitości.

W niej człowiek zbiera owoce w radości,

Obrzyna wino, orze i zasiewa,

Skąd i na przyszły rok użytki miewa.

$$
\text { http://rcin.org. pl }
$$


[4]

Zgrzybiały starzec w futra się odziewa,

Ręce u ognia ostygłe zagrzewa;

Także i młodzi przy ciepłym kominie

Radzi siadają, póki zima minie ${ }^{22}$.

Polska adaptacja zignorowała azjańską stylistykę Juniusa, skupiając się na odartych z szumnych epitetów informacjach praktycznych. Zdawkowe opisy personifikacji poeta uzupełniał niekiedy o detale podpatrzone na rycinach, w oryginale odpowiedników nie mają bowiem wzmianki o sokole i łuku w przypadku uosobienia wiosny czy o młodzieży grzejącej się przy kominku (znamienne, że piecucha Samuiła nie zainteresowali na tej ilustracji jego rówieśnicy bawiący się na ślizgawce).

\section{Cztery części dnia a cykl rycin Quatuor temporis partes et intervalla Tobiasa Verhaechta}

Zanim Goltzius wprowadził modę na ilustrowanie pór dnia scenkami z życia codziennego (jak w cyklu zaprojektowanym ok. 1594 roku, rytowanym przez Jana Saenredama), a Jan van de Velde Młodszy - w postaci sugestywnych krajobrazów, w poświęconych temu tematowi cyklach graficznych niderlandzkich manierystów dominowały wizerunki korzystające $z$ alegorycznych personifikacji projektowanych na wzór przedstawień antycznych bóstw ${ }^{23}$. Inwentorem takiej serii, w 1582 roku rytowanej przez Jana Sadelera, był Dirck Barendszoon. Na stworzonych przez niego rycinach spoczywające na chmurach nagie uosobienia świtu, południa, wieczoru i nocy wypełniaja górna połowę, pod nimi zaś ukazane zostały scenki rodzajowe odpowiadające danej porze doby. Na pierwszym miedziorycie umieszczono sygnaturę inwentora i wykonawcy, a nawet podane zostało miejsce i data druku („Coloniae. M.D.LXXXII”) oraz imprimatur („Cum gratia et privil. S.C.M.”), brak natomiast informacji o tym, kto był twórcą 6-wersowych epigramatów, którymi podpisano poszczególne ilustracje (il. 6) ${ }^{24}$.

Sztychowana przez Sadelera seria cieszyła się sporym powodzeniem. Przed rokiem 1597 wzorował na niej swój projekt de Vos. Zrealizował go Adriaen Collaert, a stworzenie nowych inskrypcji zlecono wówczas poecie Cornelisowi Kiliaanowi ${ }^{25}$. $Z$ kolei Verhaecht zmienił proporcje kompozycji poprzedników, zmniejszając wizerunki bóstw patronujących poszczególnym porom doby, by więcej miejsca przeznaczyć na urokliwe pejzaże, jednak anonimowe inskrypcje flamandzki artysta przeją Latijnsche gedichten. Uitgegeven en met een levensbericht voorzien M. Roos es. Antwerpen 1880 , s. 96-97: Diei et aetatum divisio. 


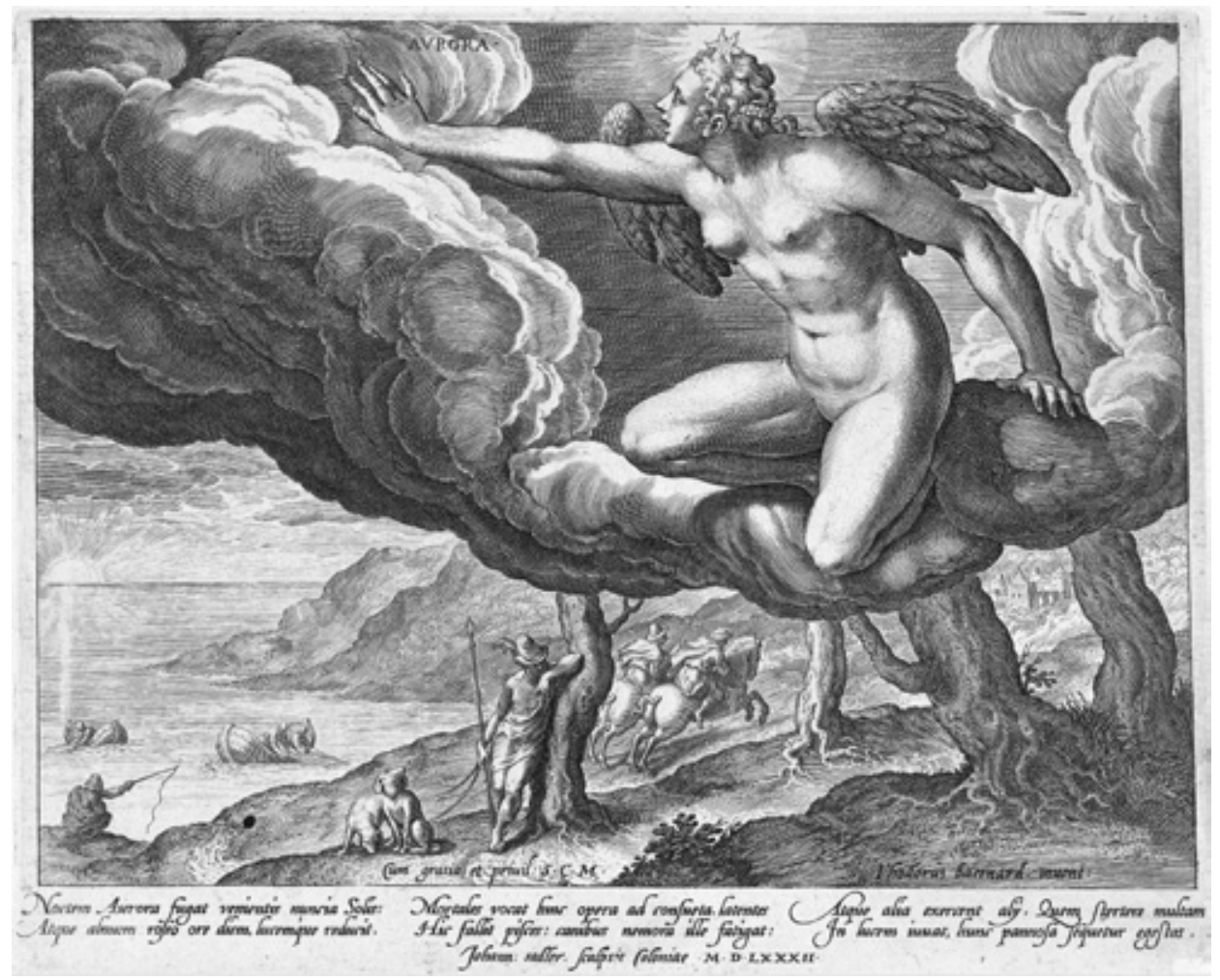

6. Jutrzenka z cyklu czterech pór dnia, proj. D. Barendszoon, ryt. J. Sadeler, 1582 (egz. Rijksprentenkabinet, Amsterdam)

z serii Barendszoona-Sadelera bez zmian. Realizacji projektu Verhaechta zapewne po 1606 roku podjął się Egbert van Panderen. Pierwszym wydawcą był Teodoor Galle, kolejnym zaś jego syn, Jan, który prasował zestaw rycin w 1638 roku. Wówczas też nadał mu tytuł: Quatuor temporis partes et intervalla (Cztery przedziały i pory doby).

Pierwsza rycina serii Verhaechta - van Panderena, zatytułowana Aurora (Jutrzenka), poświęcona została świtowi. Przedstawiona w jej górnej części Jutrzenka patronuje wiejskiej scence: na pierwszym planie pasterze przygotowują się do pędzenia stada kóz na pastwisko, na drugim myśliwi szczują zające, w tle zaś rybacy zastawiają sieci w rzece. Działania te komentuje inskrypcja (il. 7):
Noctem Aurora fugat venientis nuncia solis Atque almum roseo ore diem, lucemque reducit. Mortales vocat hinc opera ad consueta latentes Hic fallit pisces: canibus nemora ille fatigat: Atque alia exercentalii. Quem stertere multam In lucem iuvat, hunc pannosa sequetur egestas.

Druga ilustracja, Meridies (Południe), przedstawia m.in. żniwiarzy odpoczywających i posilających się w cieniu drzew, konie zaprzężone do wozu z sianem, rów- 


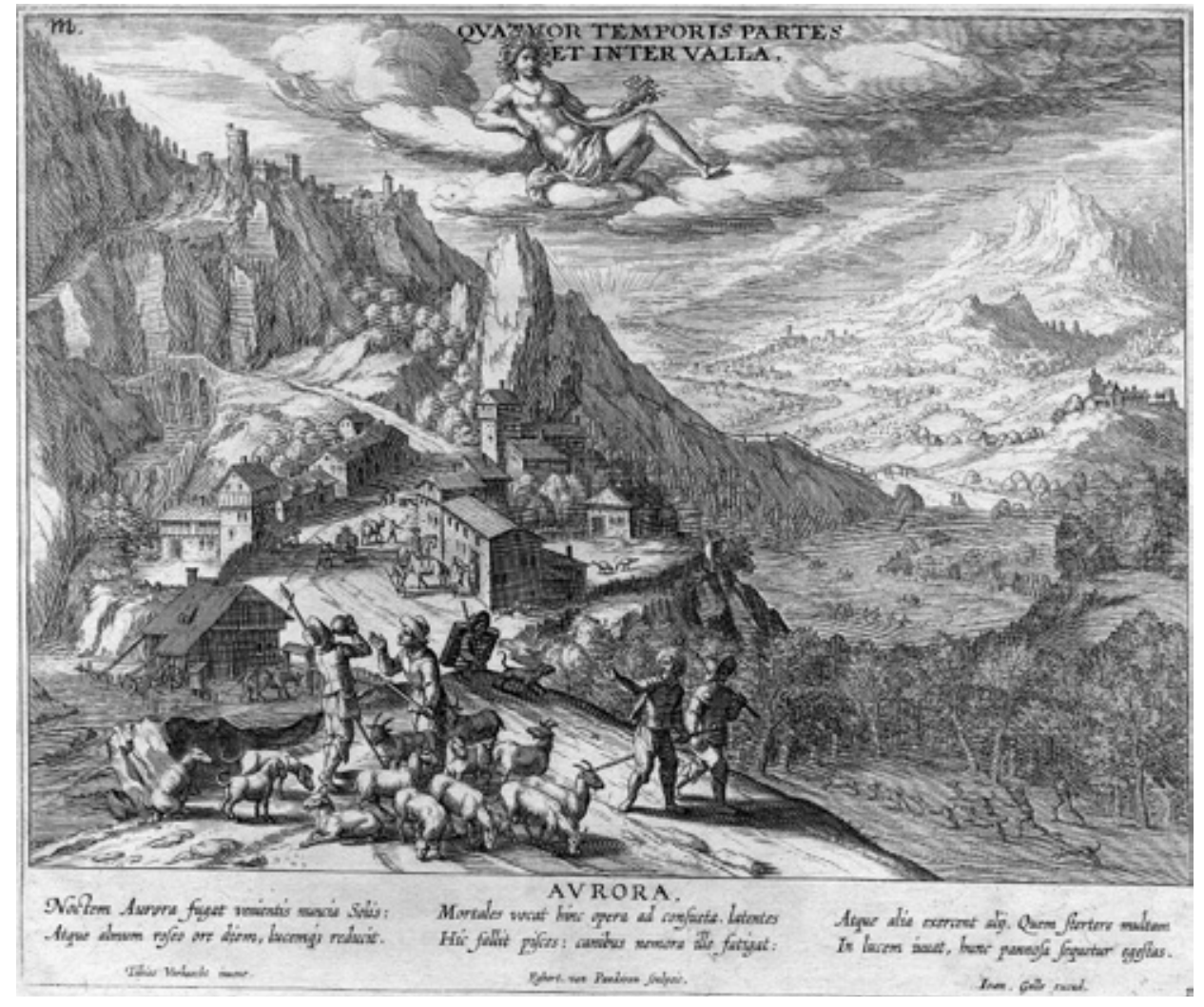

7. Jutrzenka z cyklu Quatuor temporis partes et intervalla, proj. T. Verhaecht, ryt. E. van Panderen, po 1606 [?] (wyd. 3, egz. British Museum, Londyn)

nież szukające ochłody w zacienionym miejscu, oraz stado owiec prowadzone do zagrody. Scence patronuje Febus, ukazany w postaci półnagiego młodzieńca:

Iam medium coeli Phoebus pervenit ad axem:

Urit et altusagros. Quare aestum animalia in umbra

Torrentem patula vitant: fessiquelabore

Messores, dapibusque, et somno corpora curant.

Sic Natura parens dedit esse vicesque modumque

Constituit stabilem servent ut cuncta tenorem.

Na rycinie zatytułowanej Vespera (Wieczór) widać wieśniaków wracających po pracy do swoich domostw, gdzie czekaja ich kolacja, odpoczynek i wieczorne zabawy. Na chmurach przedstawiona została naga żeńska personifikacja $z$ chusta wypełniona powiewem wiatru, zazwyczaj będacca atrybutem Fortuny. Inskrypcja tak komentuje ów wizerunek:

Solis ut Aurora est, nigrae sic nuncia Noctis

Vespera. consueta haec pecus ad praesepia cogit:

Agricolas quoque suspensis hortatur aratris,

Mortales pariter; Cereali ut munere vires 
Defessas reparent: placidae dent membra quieti:

Solamen gravium quam Dii statuere laborum.

Serię zamyka Nox (Noc). Pieczę nad nią sprawuje śpiący na chmurze półnagi starzec, wokół którego latają nietoperze. Pod nim na miejskim placu z fontanną Neptuna rozgrywa się nokturnowa scena. Obok korowodu rozbawionych przebierańców, spaceru zakochanej pary czy serenady pod panieńskim oknem przy akompaniamencie grajków widać tam również w tle, jak trzech mężczyzn atakuje zbrojnie czwartego, dokonując rozboju. Na ukazaną w ten sposób ambiwalencję nocnej pory zwraca uwagę tekst dołączonego epigramatu (il. 8):
Inducit terris densas Nox atra tenebras.
Ad mala saepe faces licet haec, ansamque ministret
Audenti quodcunque scelus, quo coeca ruit mens:
Attamen ipsa suos et habet ludosque, Iocosque,
Commodaque interdum. Sed, qui sapit, ille tenebras
Exosus; lucem, ne forte offendat, amabit.

Pisząc cykl Cztery części dnia, autor z Połocka miał w rękach wznowienie zaprojektowanej przez Verhaechta serii, które w 1638 roku wydał Jan Galle. Spolszczenie na ogół skraca łacińskie inskrypcje do 4-wersowych epigramatów pozbawionych moralizującej puenty podstawy adaptacji (poza ostatnim, który zachował oryginalną liczbę wersów i z całego cyklu najbliższy jest wiernemu przekładowi), przez co zyskuje na dobitności:

\section{CZTERY CZEŚSI DNIA}

[1]

Zorza rozpędza umbry światła ciemne, Słońca promienie zwiastuje przyjemne, Gospodarzowi nastaje robota,

Szczuje myśliwiec w ciemnym gaju kota.

[2]

Gdy się w pół nieba wzbierze Febus złoty, Posiłek bierze, spocznie od roboty Strudzony człowiek, zwierzęta do wody Lub w cień kwapią się, szukając ochłody.

[3]

Słońce $\mathrm{z}$ południa gdy na zachód przydzie, Człowiek do domu, bydło w chlewy idzie, Aby po pracej ciało utrudzone Wdzięcznym snem było nieco ożywione.

[4]

Ciemna noc skrzydła rozpostarszy swoje, Czyni po drogach, w miastach niepokoje Ma-ć wprawdzie człowiek z niej podczas wygodę, Ale najwięcej czyni ludziom szkodę. Przeto, kto mądry, ma noc w nienawiści, We dnie uciechy szuka i korzyści ${ }^{26}$. 


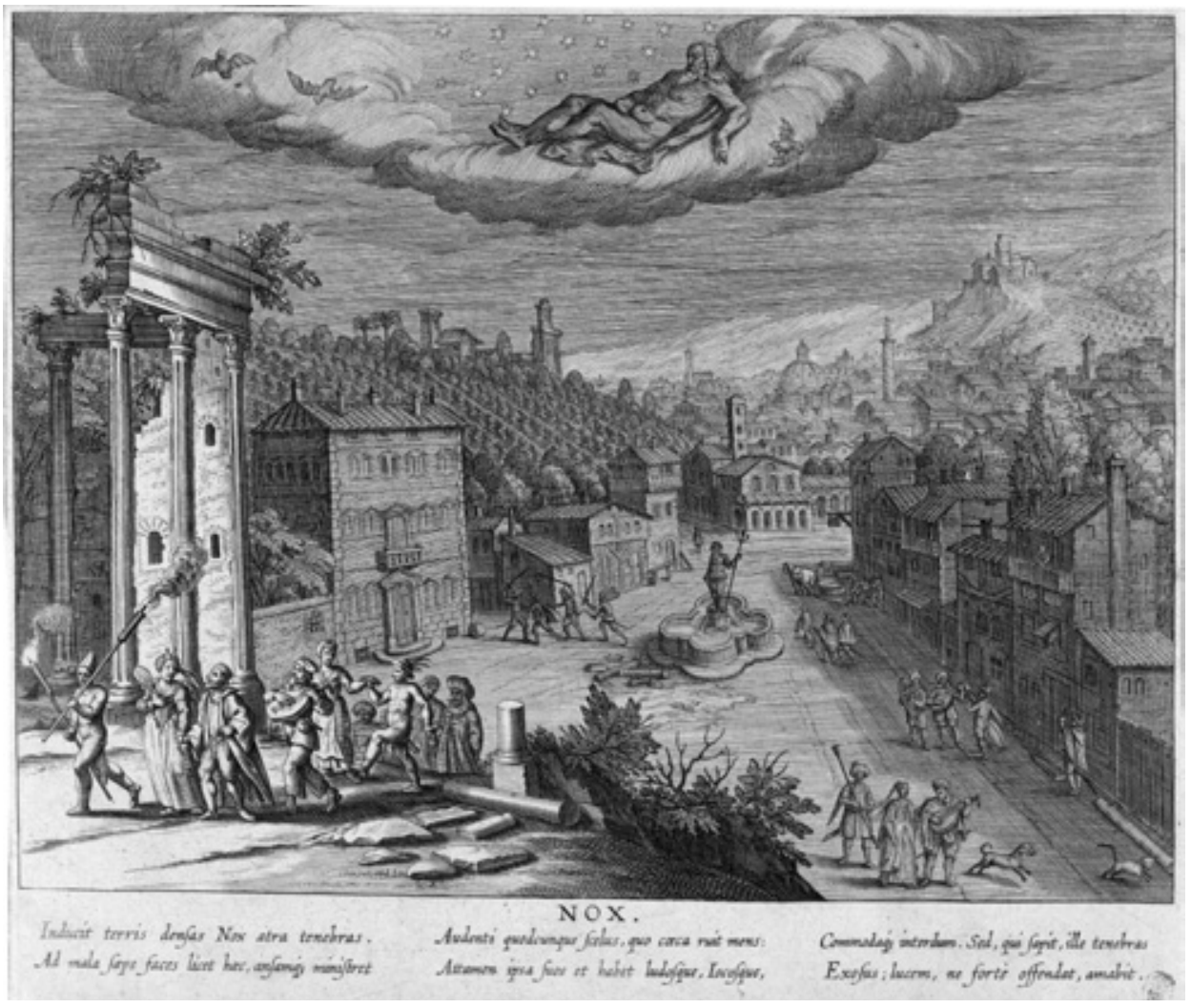

8. Noc z cyklu Quatuor temporis partes et intervalla, proj. T. Verhaecht, ryt. E. van Panderen, po 1606 [?] (egz. Rijksprentenkabinet, Amsterdam)

Luźna adaptacja 6-wersowych inskrypcji antwerpskich rycin musiała dręczyć sumienie artystyczne Piotrowskiego-Sitnianowicza, skoro niezależnie od polskiej wersji opracował on również cerkiewnosłowiańską, tym razem będącą wiernym przekładem oryginału. Tę młodzieńczą najpewniej pracę o tytule Dien' i noszcz (Dzień i noc) po latach włączył poeta do obszernego zbioru Wiertograd mnogocwietnyj (Wirydarz wielu kwiatów) ${ }^{27}$. Na zależność obu wersji językowych autorstwa poety z Połocka pierwszy zwrócił uwagę Ryszard Łużny. Nie podejrzewając istnienia wspólnego łacińskiego źródła epigramatycznych cykli Cztery części dnia oraz Dien'

S. Polockij, Vertograd mnogocvětnyj. Ed. A. Hip pisley, L. I. Sazonova. Foreword D. S. Lic h a č ev. T. 1: „Aaron” - „Détemblagoslovenie”. Köln 1996, s. 263-264. Wydawcy nie rozpoznali w rosyjskim cyklu przekładu z łaciny, przemilczeli również jego zbieżność z Czterema częściami dnia (ibidem, s. 349). Zob. S. I. N i k oł aj e w: Polskaja poezija $w$ russkich pieriewodach. Wtoraja połowina XVII - pierwajatriet' XVIII wieka. Leningrad 1989, s. 28; Mikołaj Kochanowski w opracowaniu Symeona Połockiego. W: Od Kochanowskiego do Mickiewicza. Szkice z historii polsko-rosyjskich zwiazków literackich XVII-XIX wieku. Przeł. J. G ła ż ew s ki. Warszawa 2007, s. 58. 
i noszcz, polski scharakteryzował jako pozbawiony „prawie całkowicie tak charakterystycznego dla pozostałych utworów "mentorstwa":

Rzecz ciekawa, że kiedy w latach późniejszych Połocki część wierszy z tego zbioru (chodzi tu przede wszystkim o wiersze ruskie) przenosił do przygotowywanej antologii Ogród wielu kwiatów, dołączył do nich również ten polski utwór [tj. utwór cerkiewnosłowiański pisany na ten sam temat - R. G.]. Zachowując zasadniczą jego treść oraz sposób jej ujęcia, autor znacznie rozwinął wówczas [...] element moralizatorski, dodając do każdej zwrotki [z wyjątkiem ostatniej - R. G.] po dwa wiersze i wzmacniając alegoryczną, wtórną interpretację nakreślonych obrazów ${ }^{28}$.

Dzięki wskazaniu łacińskiego oryginału dla literalnego przekładu cerkiewnosłowiańskiego oraz skróconej adaptacji polskojęzycznej można stwierdzić, że w rzeczywistości było odwrotnie, niż podejrzewał Łużny. Autorem owych „mentorskich” puent był współpracujący z Goltziusem poeta nowołaciński. Wileński student raz pokusił się o ich przekład, raz nie - widać nie zawsze cenił morały. Niekiedy mocniej doń przemawiały scenki rodzajowe, lepiej przystające do poetyki lekkiej fraszki, a umoralniające przesłania swoich epigramatów zawdzięczał czasem nie tyle własnym preferencjom, ile wiernemu tłumaczeniu tekstów wzorcowych.

\section{Cztery żywioły $i$ skutki onych a cykl rycin Quatuor elementa, eorumque effectus Maartena de Vosa $\mathrm{z}$ około 1582 roku}

Według wciąż obowiązującej w XVI i XVII stuleciu antycznej koncepcji świat podksiężycowy składał się z czterech zantagonizowanych żywiołów, które układały się sferycznie od najcięższej ziemi po najlżejszy ogień. Niezawodny w takich przypadkach Owidiusz wyjaśniał (Metamorphoses XV, w. 239-245):

\footnotetext{
Wieczny świat cztery ciała rodzajne ma w sobie,

A z tych dwie, że ciężkie są, ciężarem swym obie,

Ziemia i woda, dolne osiadły niskości.

Tyleż ich też jest próznych wszelakiej ciężkości,

Przeto choć ich do tego żaden nie niewoli,

Na górną się wysokość wzbieły z dobrej woli:

Powietrze i chędoższy ogień nad nie jeszcze.

A lubo ich odległe $z$ sobą dzieli miejsce,

Wszytko jednak, cokolwiek świat ma, z nich się rodzi,

Bo jak ony we wszytko, tak w nie wszytko wchodzi ${ }^{29}$.
}

Dawni poeci stosunkowo rzadko przypominali ów komunał (a i wówczas ograniczali się zwykle do zdawkowej wzmianki pokroju tej, którą spotykamy u Mikołaja Sępa Szarzyńskiego: „Ogniem wiatr przykrył, dzierżą ziemię wody, / różnym naturom kazał użyć zgody") ${ }^{30}$, natomiast wizerunki personifikacji poszczególnych

R. Łużny, Pisarze kręgu Akademii Kijowsko-Mohylańskiej a literatura polska. Z dziejów związów kulturalnych polsko-wschodniosłowiańskich $w$ XVII-XVIII w. Kraków 1966, s. 120. Rosyjski przekład tego akapitu Łużnego ostatni rosyjscy wydawcy, zatajając autora, włączyli do objaśnień rzeczowych edycji jako własny komentarz do cyklu Cztery części dnia (zob. 2014, s. 295).

Ovidius Naso, op. cit., s. 615.

30 M. Sęp Szarzyński, Pieśń 3. O wielmożności Bożej, w. 17-18. W: Poezje zebrane. Wyd. R. Grześk owiak, A. Karpiński, przy współpr. K. Mrow cewi cza. Warszawa 2001, s. 49. 
żywiołów były modnym tematem cykli graficznych. Popularność skutkowała rozmaitymi rozwiązaniami ikonograficznymi. Obok tradycyjnych przedstawień łączących uosobienie substancji podstawowej z wybranymi zwierzętami (lądowymi, morskimi, ptakami, salamandrą lub feniksem) rozpowszechnione były grafiki odwołujące się do tradycji mitologicznej (Kybele, Neptun, Junona, Jowisz lub Wulkan), a z początkiem XVII wieku zaczęły pojawiać się ilustracje, na których alegorie zostały zastapione przez werystyczne scenki $\mathrm{z}$ reprezentantami różnych zawodów - pojedynczymi bądź w miłosnych parach z młodymi kobietami (np. zestawienie czterech wizerunków: myśliwy lub muzyk; rybak; ptasznik; kucharz lub złotnik) ${ }^{31}$.

Piotrowski-Sitnianowicz inspirował się jedynym z kilku cykli, które na ten temat zaprojektował de Vos. Do dziś zachowały się trzy spośród jego czterech szkiców rycin serii, sygnowane na 1582 rok $^{32}$. Ilustracje owe, ukazujace nagie personifikacje na tle kolejnych żywiołów i zamieszkujących je zwierząt, zakomponowane zostały na planie prostokata, poza pierwszą, poświęconą ziemi, która miała taką samą podstawę, ale pierwotnie została zwieńczona owalnie. Ich miedzioryty wykonał Adriaen Collaert, a pierwszym wydawcą był Gerard de Jode, podpisany na inicjalnej grafice serii notą umieszczoną na dyni: „G. d. Jode excu[dit]”. Następny drukarz, Theodoor Galle, uzupełnił tło w górnych rogach pierwszej ilustracji, nadając jej postać regularnego prostokata, a także dodał numerację rycin. W roku 1638 płyty po raz kolejny odbił syn Theodoora, Jan, przy okazji tytułując poszczególne ilustracje: Terra, Aqua, Aer, Ignis, oraz cały cykl: Quatuor elementa eorumque effectus (Cztery żywioły i ich skutki).

Każda $z$ rycin opatrzona została łacińskim dystychem, sztycharz nie ujawnił jednak autora owych 2-wierszy. Personifikacja ziemi ma tu postać nagiej kobiety siedzacej na pniu. Po jej lewej stronie ukazane są owoce i niemowlę, po prawej zaś kościotrup. Do sceny tej nawiązuje inskrypcja (il. 9):

E terra ut rerum primordia cuncta refurgunt,

Sic rursum in terram mortua cuncta cadunt.

BPS 23. Por. np. przypomnienie S. S. Sz e mi o ta (Komparacyja człowieka do świata [...], w. 9-12. W: Sumariusz wierszów. Z rękopisu wyd. i oprac. M. K o r ol k o. Warszawa 1981, s. 169): „Cztyry kolumny machinę wspierają / światową: jedną ogniem nazywają, / drugą powietrzem, ziemia trzecia będzie, / czwarta w tymże się woda kładzie rzędzie”, czy wyliczenie właściwości żywiołów pióra J. Ż a bc zy c a (Quaternijo, $w$ którym się wyrażają Boskie sprawy niepojęte aniołów, nieba,

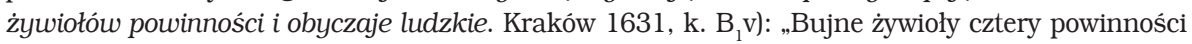
mają: / ogień pali, wiatr suszy, woda z ziemią znają / wilgotność i surowość. Te z sobą złączone / pomiarem odżywiają bytności stworzone".

31 Zob. np. K. P o p it z, Die Darstellung der vier Elemente in der niederländischen Graphik von 1565 bis 1630. München 1965. - V el d m a n: Goltzius' Zintuigen, Seizoenen, Elementen, Planeten en Vier tijden van de dag, s. 319-323; Images for the Eye and Soul, s. 202-205. M. P o k o r s k a - P r i m u s, Planety, żywioły i temperamenty $w$ rycinach niderlandzkiego manieryzmu. „Alma Mater” 120/121 (2009/10), s. 24-25. Zob. też Ri pa, op. cit., s. 219-221.

32 Szkic z personifikacją ziemi przechowywany jest w Lyman Allyn Art Museum w New London (nr inw. 1963.88), ognia w Rijksmuseum w Amsterdamie (nr inw. 54:111), wody zaś w 1993 r. był dostępny na rynku antykwarycznym. Zob. Hollstein's Dutch and Flemish Etchings, Engravings and Woodcuts 1450-1700. T. 44: Maarten de Vos. Text. Comp. Ch. Schuckman. Ed. D. De Hoop Scheffer. Rotterdam 1996, s. 270-271. 


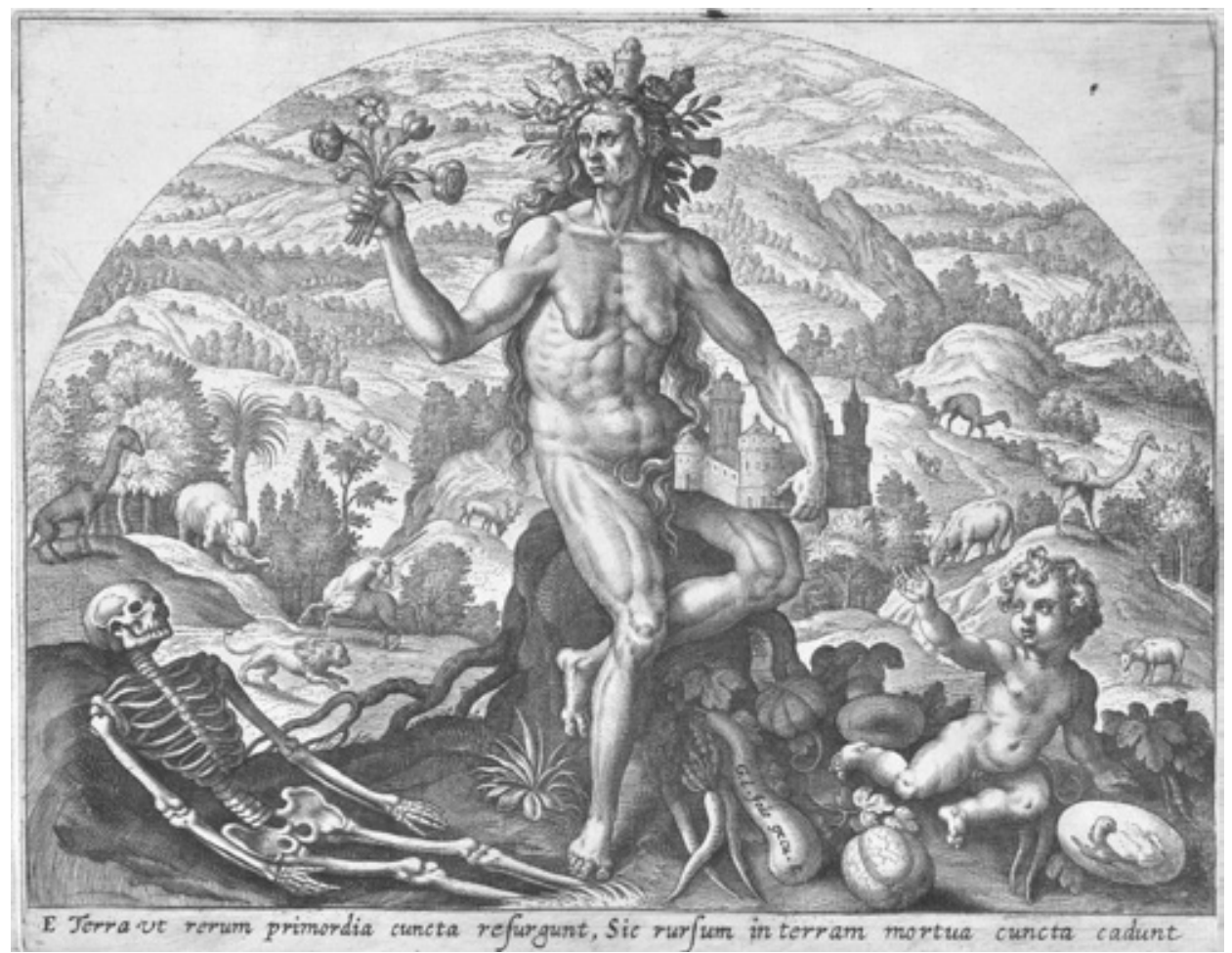

9. Ziemia z cyklu Quatuor elementa, eorumque effectus, proj. M. de Vos, ryt. A. Collaert, ok. 1582 (pierwodruk, egz. Rijksprentenkabinet, Amsterdam)

Wizerunek wody, młoda kobieta siedząca na ustawionych na półksiężycu muszlach w otoczeniu morskich stworzeń, w jednej ręce trzyma okręt, w drugiej busolę. Towarzyszacy jej podpis głosi:

Humiditate mea plantae campique virescunt Piscibus et vitam munere reddo meo.

Powietrze zobrazowane zostało przez dojrzałego mężczyznę w otoczeniu ptaków, skrzydlatych owadów i personifikacji wiatrów (il. 10):

Omnia ego foveo et vegeto, quae terra creavit Nil sine me vitam ducere namque potest.

Natomiast ukazany pod postacią młodzieńca ogień w jednym ręku trzyma salamandrę, drugą nadstawia nadlatującemu feniksowi. Inskrypcja zwraca uwagę na paradoksalną naturę żywiołu:

Mortua cuncta iacent si non serventur ab igne, Omnia vivificat namque calore suo ${ }^{33}$. 


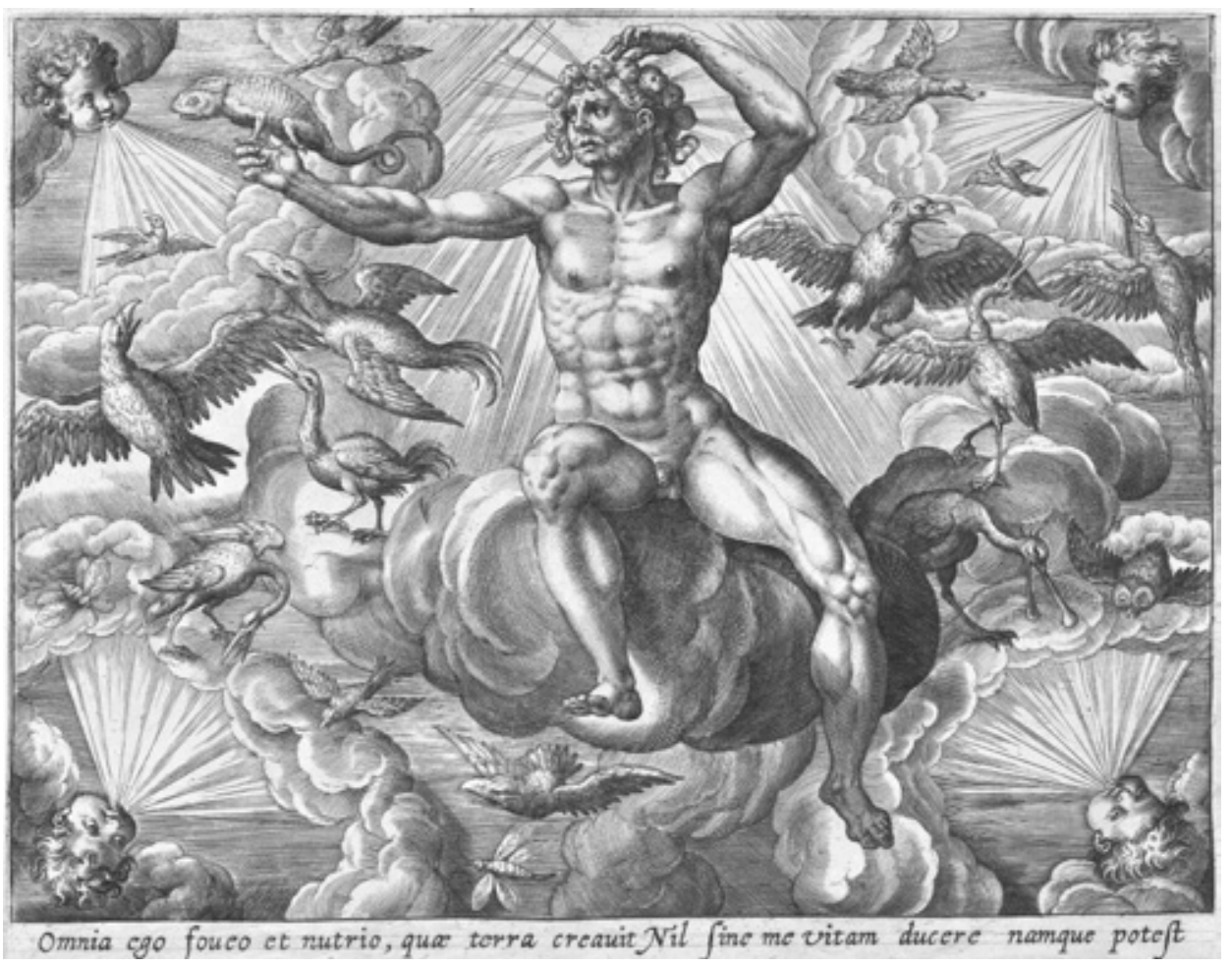

10. Powietrze z cyklu Quatuor elementa, eorumque effectus, proj. M. de Vos, ryt. A. Collaert, ok. 1582 (egz. Rijksprentenkabinet, Amsterdam)

Dla wileńskiego studenta temat musiał być atrakcyjny, skoro anonimowe łacińskie dystychy amplifikował do 4-wierszy:

CZTERY ŻYWIOŁY I SKUTKI ONYCH

[1]

Ziemia ciężary wszytkie dźwiga sobą,

Drzew, kwiecia, zwierząt upstrzona ozdobą.

Wszech rzeczy matka wszytko ona rodzi,

Lecz zaś pożera, co też kolwiek spłodzi.

[2]

Woda mokrością las, trawę zieleni,

Żeglarz ją sławi, który się nie leni.

Baleny straszne i wielorybowie

W niej i z niej żyją, morscy też zwierzowie.

[3]

„Cokolwiek ziemia i morze zarodzi,

To się bez mojej łaski nie rozpłodzi.

s. 270-271. - Jw. T. 46: Maarten de Vos. Plates, part II. Comp. Ch. Schuckman. Ed. D. De

Ho op Scheffer. Rotterdam 1995, s. 183-184: nry 1349-1352. 
Ja to, powietrze, wszytkim żywot daję,

Gdy wiatry puszczam na wsze świata kraje”.

[4]

„Wszystko by ginąc bez czasu musiało,

By nie ode mnie łaski doznawało.

Ja, ogień, siadszy aż przy samym niebie,

Ciepłem wygadzam wszech rzeczy potrzebie" 34 .

Piotrowski-Sitnianowicz korzystał ze wznowienia cyklu graficznego z 1638 roku. Wiernie przełożył przypisany mu wówczas tytuł, ale tłumacząc poszczególne epigramaty, niekiedy inspirował się również szczegółami sugestywnych ilustracji. W oryginale inskrypcje towarzyszace przedstawieniom wody i powietrza sformułowane zostały w pierwszej osobie, jako kwestie samych żywiołów. Przekładając pierwszą $z$ wymienionych, poeta zamienił wypowiedź na trzecioosobową, nadając jej taki sam ogólny charakter, jaki ma pierwszy epigramat serii. Do pomysłu nowołacińskiego autora przekonał się dopiero, kiedy spolszczył inskrypcję dotycząca powietrza. Wbrew oryginałowi narracje pierwszoosobową wprowadził również do ostatniego epigramatu, poświęconego ambiwalencji ognia.

W rękopiśmiennych przekazach zawierających wczesna twórczość poetycką Symeona z Połocka zachował się ułożony w języku cerkiewnosłowiańskim cykl poświęcony temu samemu tematowi, który autor włączył do kompilowanego w drugiej połowie lat siedemdziesiątych XVII stulecia zbioru Wiertograd mnogocwietnyj, nadając mu wówczas tytuł Stichii czetyri (Cztery żywioły) ${ }^{35}$. W odróżnieniu od dzieł Cztery części dnia oraz Dien' i noszcz, posiadających wspólne łacińskie źródło, a tym samym wykazujących szereg wyraźnych zbieżności treściowych, obie wersje językowe epigramatów poświęconych czterem elementom odmiennie opracowują temat $^{36}$. Inaczej niż łacińskie inskrypcje cyklu de Vosa - Collaerta i ich polska adaptacja, Stichii czetyri skupiają się na podkreślaniu wagi poszczególnych żywiołów, decydującej o ich wzajemnym położeniu (ziemia została tu przedstawiona jako najniższa, wodami otoczony jest ziemski krag, powietrze $z$ kolei wisi nad wodami i ziemią, przechodząc je lekkością, choć cięższe jest od ognia) - zbliżając się tym samym do przywołanego ustępu Metamorfoz Owidiusza, stanowiącego częsty punkt odniesienia dla rozważań poetyckich poświęconych temu tematowi, także w inskrypcjach dołaczanych do rycin. W wersji cerkiewnosłowiańskiej brak również zamiany narratora $z$ trzecio- na pierwszoosobowego. Daleko idące różnice każą podejrzewać, iż Stichii czetyri stanowią adaptację inskrypcji innego cyklu graficznego $z$ przedstawieniem czterech elementów.

Tekst cyklu za przekazami: rkps 1800, k. 117r-v; rkps 731, k. 149v-150r (por. edycje: 1990, s. 112; 2000, s. 183; 2014, s. 248).

Rkpsy: 731, k. 6r (bez tytułu); Rosyjskie Państwowe Archiwum Akt Dawnych w Moskwie, Kolekcja Drukarni Synodalnej, font 381, nr 389, k. 123r (tytuł dopisany przez S. Miedwiediewa: Stichii). Zob. S. P ol o c kij, Vertograd mnogocvětnyj, t. 3: „Prav nikto že” - „Epitafion” Simeonu. Köln 2000, s. 592. Zob. też Ni kołaj e w: Polskaja poezija w russkich pieriewodach, loc. cit;; Mikołaj Kochanowski $w$ opracowaniu Symeona Połockiego, s. 59 (badacz, wskazując na wspólny temat cykli Cztery żywioły i skutki onych oraz Stichii czetyri, ten drugi uznał za autorski przekład pierwszego). 


\section{Cztery przemagajace kompleksyje a cykl rycin Quatuor praedominantes complexiones Maartena van Heemskercka z 1566 roku}

W czasach Piotrowskiego-Sitnianowicza teoria humoralna wciąż jeszcze była podstawą praktyk medycznych. Zgodnie $z$ nią jakości w świecie składające się na cztery żywioły w organizmie człowieka konstytuowane miały być przez cztery humory: krew, żółć (cholerę), flegmę i czarną żółć (melancholię); ich proporcje nie tylko ważyły na zdrowiu, ale również warunkowały ludzki temperament. W zależności od tego, który humor u kogoś dominował, posiadał ów ktoś usposobienie sangwiniczne, choleryczne, flegmatyczne lub melancholiczne. Powszechnie znana teoria, propagowana $\mathrm{w}$ niezliczonych pracach medycznych poświęcanych różnym zagadnieniom szczegółowym ${ }^{37}$, dla staropolskich literatów nie była atrakcyjnym tematem. Poeci co najwyżej ograniczali się do przypomnienia truizmu, iż ciało ludzkie składa się z korespondującej z żywiołami tetrady. Czynili tak choćby Wacław Potocki:

Cztery człowiecze ciało przeciwne składają

Żywioły i wszytkie w nim swoję cząstkę mają:

Ogień ciepło, krew wodę człowiekowi daje,

Powietrze oddech, $\mathrm{z}$ ziemie nasze ciało wstaje

- czy Stanisław Samuel Szemiot:

Takież podpory człowieka dźwigają,

Te-ż elementa w życiu pomagają,

A że są w kożdym, o tym wątpić szkoda:

Ziemia, powietrze, ogien, czwarta woda ${ }^{38}$.

Bodaj tylko ten ostatni - podrzędny rymopis, mający ambicję powtarzać w mowie wiązanej powszechne fabuły i zagadnienia popularyzowane dotąd prozą ${ }^{39}$ próbował przekształcić koncepcję humoralną w temat poetycki, przewierszowując uwagi poradnika medycznego w klucz do oznaczania temperamentów ${ }^{40}$.

Rzadkość opracowania owego tematu sprawia, że kolejny cykl Piotrowskiego-Sitnianowicza jest tak intrygujący:

37 Kompilacyjną dysertację akademicką w czasie swych studiów medycznych w Bazylei poświęcił jej choćby D. Naborowski. Zob. J. D ü r r - D u r s k i, Daniel Naborowski. Monografia z dziejów manieryzmu i baroku w Polsce. Łódź 1966, s. 20-24. - A. Ra u b o, Zapomniane dzieło Daniela Naborowskiego „De temperamentis disputatio medica” (1593). „Przestrzenie Teorii” t. 24 (2015).

W. P o t o cki, Tydzień stworzenia świata, w. 581-584. Lwowska Narodowa Naukowa Biblioteka Ukrainy im. W. Stefanyka, Zbiór Ossolińskich, rkps sygn. 5888/I, s. 804. - Sze mi ot, op. cit., s. 169, II 22, w. 13-16. Zob. też M. H a n u s i ew i c z, Święte i zmysłowe w poezji religijnej polskiego baroku. Lublin 1998, s. 87-101. - A. B or k o w s ki, Imaginarium symboliczne Wactawa Potockiego: „Ogród nieplewiony”. Siedlce 2011, s. 133-159.

39 Zob. np. D. Ch e m per ek, Szemiot - epigramatysta. „Annales Universitatis Mariae Curie-Skłodowska”, Sectio FF: „Philologiae” t. 23 (2005). - J. P a r ty k a, O źródłach „Sentencyj albo przysłów” Stanisława Samuela Szemiota. W zb.: Człowiek $w$ literaturze polskiego baroku. Red. A. B o r k owski, M. Pliszka, A. Ziontek. Siedlce 2007.

40 Zob. S. S. S z e m i o t, Cztery kompleksyje ludzkie, które uważywszy, każdy swą naturę wyrozumieć może. W: Sumariusz wierszów, s. 171-172, II 23. 
CZTERY PRZEMAGAJĄCE KOMPLEKSYJE

[1]

Jowisz z Wenerą krwią rumianych rodzi,

Śliczny, wesoły syn ich w tany chodzi.

[2]

Mars choleryków panem się mianuje,

Bje, siecze, pali i wojny sprawuje.

[3]

Mierzą, wieszczują, sami się wieszają

Melancholicy, co z Saturna mają.

[4]

Z Luny jest flegma - tacy skłonność maja

Do wód, ryb, ptastwa, co jej podlegaja $a^{41}$.

Również w tym przypadku rozwiązaniem zagadki, dlaczego poeta $\mathrm{z}$ Połocka skusił się na temat, który innych nie nęcił, jest inspiracja cyklem graficznym. Przedstawienia czterech temperamentów w grafice po 1600 roku przestały cieszyć się taką popularnością, jak w uprzednim stuleciu, stąd potencjalnego źródła należałoby szukać raczej wśród rycin wcześniejszych. Zaprojektowane przez de Vosa dwa odmienne cykle poświęcone czterem temperamentom, zarówno rytowany przez Raphaëla Sadelera Starszego w 1583, jak i przez Pietera de Jodego Starszego pomiędzy rokiem 1590 a 1632, na wzór średniowiecznych przedstawień tematu ukazywały pary reprezentujace każdy z humorów. Na miedziorytach wydanych około roku 1596 według projektu Jacoba de Gheyna Młodszego umieszczeni zostali pojedynczy przedstawiciele poszczególnych kompleksji ${ }^{42}$. Wileńskiego studenta zainteresował jednak zaprojektowany w roku 1565 cykl Heemskercka, który obrał odmienna strategię $e^{43}$.

Na potrzeby serii haarlemski artysta zaadaptował ikonograficzny schemat przestawiania dzieci planet: w górnej części ryciny umieścił na chmurze personifikację planety patronującej danemu temperamentowi, w dole zaś osoby o przypisy-

41 Tekst cyklu za przekazami: rkps 1800, k. 117r; rkps 731, k. 149r (por. edycje: 1990, s. 116; 2000, s. $182 ; 2014$, s. 244). W epigramacie 2, w. 2, daję elizję rkpsu 731: „Bje”, zamiast hipermetrycznej lekcji: „Bije” rkpsu 1800.

42 Zob. np. R. Kalibansky, E. Pan of sky, F. S ax1, Saturn i melancholia. Studia z historii filozofii przyrody, medycyny, religii oraz sztuki. Przeł. A. Kryczyńska. Kraków 2009, s. 423426 ( $\mathrm{z}$ tytułu usuwam dwa zbędne przecinki, w stosunku do oryginału zniekształcające sens). G. L. N o t a r p, Von Heiterkeit, Zorn, Schwermut und Lethargie. Studien zur Ikonographie der vier Temperamente in der niederländischen Serien- und Genregraphik des 16. und 17. Jahrhunderts. Münster 1998.

43 Zachowały się szkice dwóch rycin datowane na 1565 r., z przedstawieniem temperamentu cholerycznego (w zbiorach Yale University Art Gallery w New Haven, nr inw. 1964.9.4.; zob. E. Haverkamp-Begemann, A.-M. S. Logan, European Drawings and Watercolors in the Yale University Art Gallery 1500-1900. T. 1. New Haven - London 1970, s. 178-179: nr 328) i flegmatycznego (w zbiorach Pierpont Morgan Library w Nowym Jorku, nr inw. 1986.7; zob. F. S t a m pfle, Netherlandish Drawings of the Fifteenth and Sixteenth Centuries and Flemish Drawings of the Seventeenth and Eighteenth Centuries in the Pierpont Morgan Library. With assist. R. S. Kr a e m e r, J. Sh oaf Turner. New York 1991, nr 73). Zob. Veld ma n, Seasons, Planets and Temperaments in the Work of Maarten van Heemskerck, s. 170, przypis 72. - Maarten van Heemskerck, s. 218-219. 


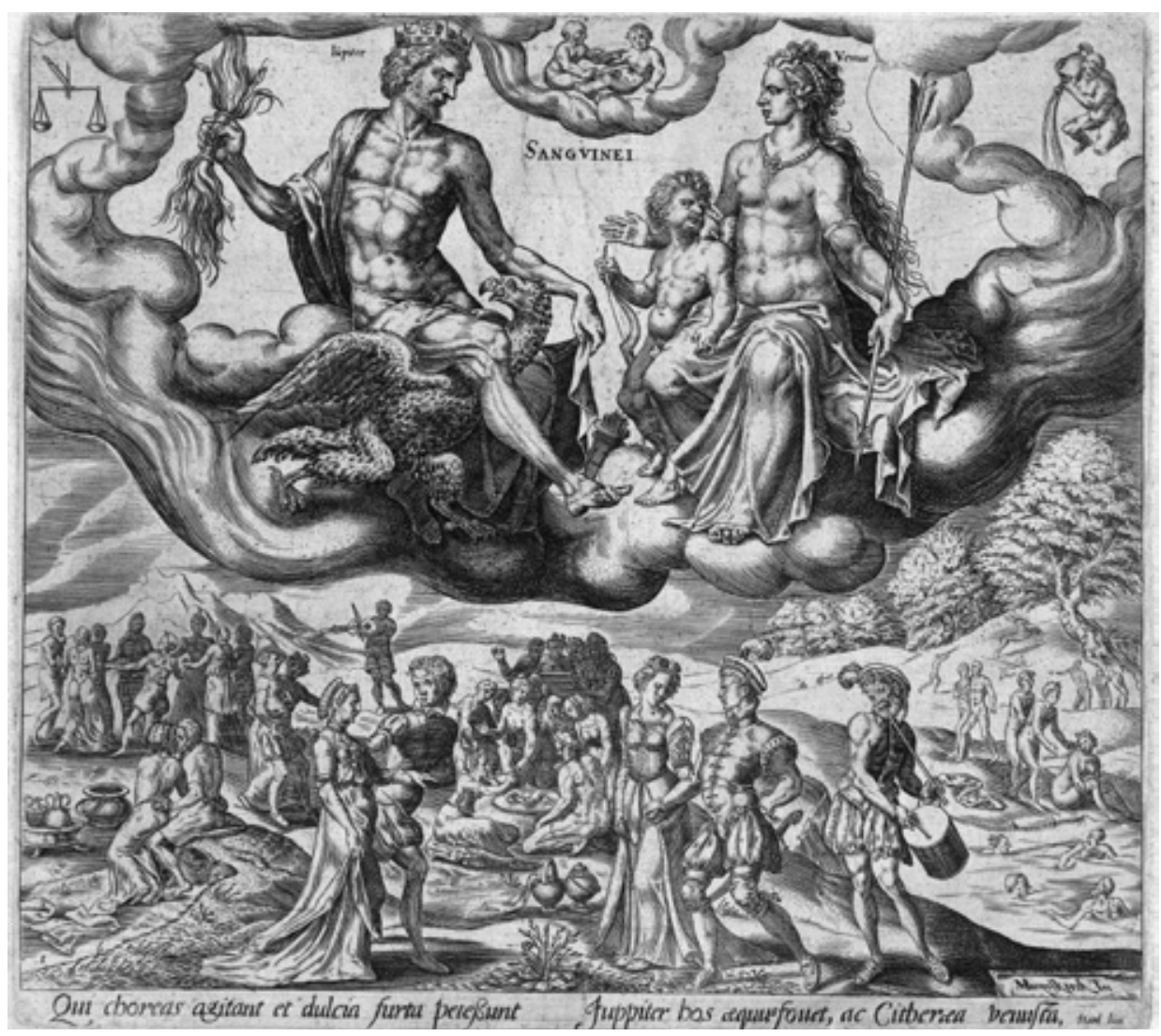

11. Sangwinicy z cyklu Quatuor praedominantes complexiones, proj. M. van Heemskerck, ryt. H. Muller, 1566 (egz. Rijksprentenkabinet, Amsterdam)

wanych mu zachowaniach lub zawodach ${ }^{44}$. Ryciny ukazały się rok później, osobnymi sygnaturami identyfikując projektanta („MHeemskerck in[venit”), rytownika Harmena Janszoona Mullera („HMuller fe[cit]”), a zniekształconym podpisem pod pierwszą inskrypcją („Hard. [!] Jun.”) również autora łacińskich dystychów - Juniusa. Także te cztery epigramaty zostały włączone do zbioru Pinaces. Lib[er] unus, który wydrukowano już po śmierci poety. Drukarz tomu nadał im wówczas własny opisowy tytuł: In quaternas pinaces hominum temperaturas complexas (Na ryciny z czterema cielesnymi kompleksjami człowieka) ${ }^{45}$.

Piotrowski-Sitnianowicz, adaptując łaciński oryginał, i w tym przypadku korzystał nie $z$ edycji Juniusa, lecz z wersji umieszczonej na miedziorytach. Ich pierwsze

44 Podobieństwo cyklu Heemskercka do przedstawień dzieci planet jest na tyle uderzające, że dodana do polskiego przekładu Saturna i melancholii reprodukcja ryciny ukazującej melancholików - na przekór informacji zawartej w tekście - została błędnie podpisana jako „Dzieci Saturna” (Ka libansky, Panofsky, Sax1, op. cit., s. 423, s. 428, il. 149).

45 Zob. Junius, op. cit., s. 158-159. 


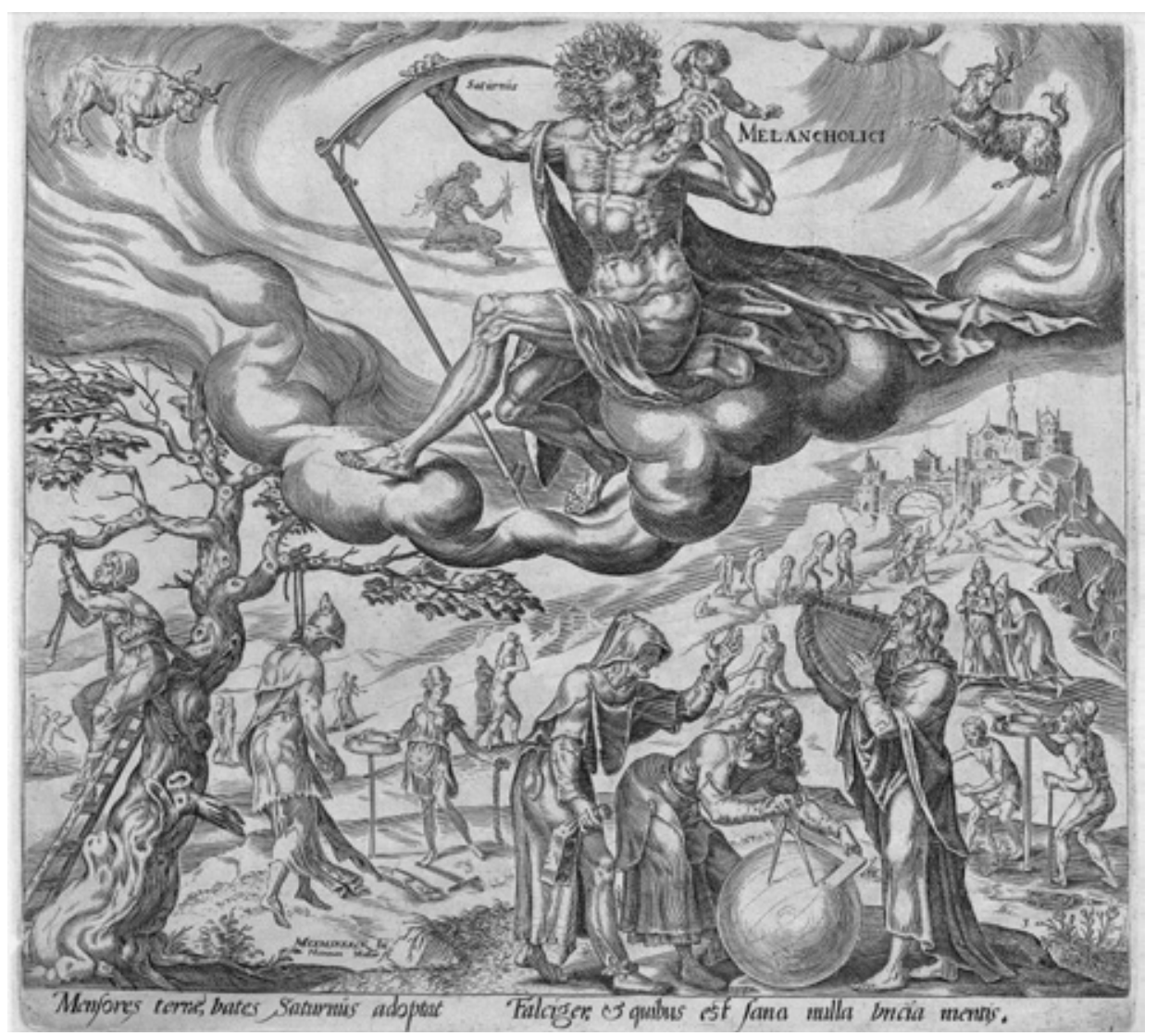

12. Melancholicy z cyklu Quatuor praedominantes complexiones, proj. M. van Heemskerck, ryt. H. Muller, 1566 (egz. Rijksprentenkabinet, Amsterdam)

wydanie ukazało się bez podania oficyny, drugie sygnował Theodoor Galle („Th. Galle exc[udit]"), trzecie, $\mathrm{z}$ roku 1638, Jan Galle (,Ioan. Galle exc[udit””). Ostatni wydawca przypisał cyklowi tytuł Quatuor praedominantes complexiones, który dosłownie spolszczył poeta z Połocka, identyfikując tym samym wariant, na którym się opierał.

Pierwsza ilustracja przedstawia sangwiników jako miłosne pary, razem tańczące, ucztujące i kapiące się, a ich planetarnymi patronami zostali Jowisz i Wenus (il. 11):

Qui choreas agitant et dulcia furta petessunt Juppiter hos aequus fovet, ac Citheraea venusta. miosłu:

Cholerycy pod okiem Marsa, walcząc i podpalając, oddają się wojennemu rzeArmorum rabies, incendia, praelia, strages Luctiferum agnoscunt Martem, dominumque cruentum.

Zjadający niemowlę Saturn groźnie spogląda na swe dzieci. Zwykle byli to http://rcin.org.pl 


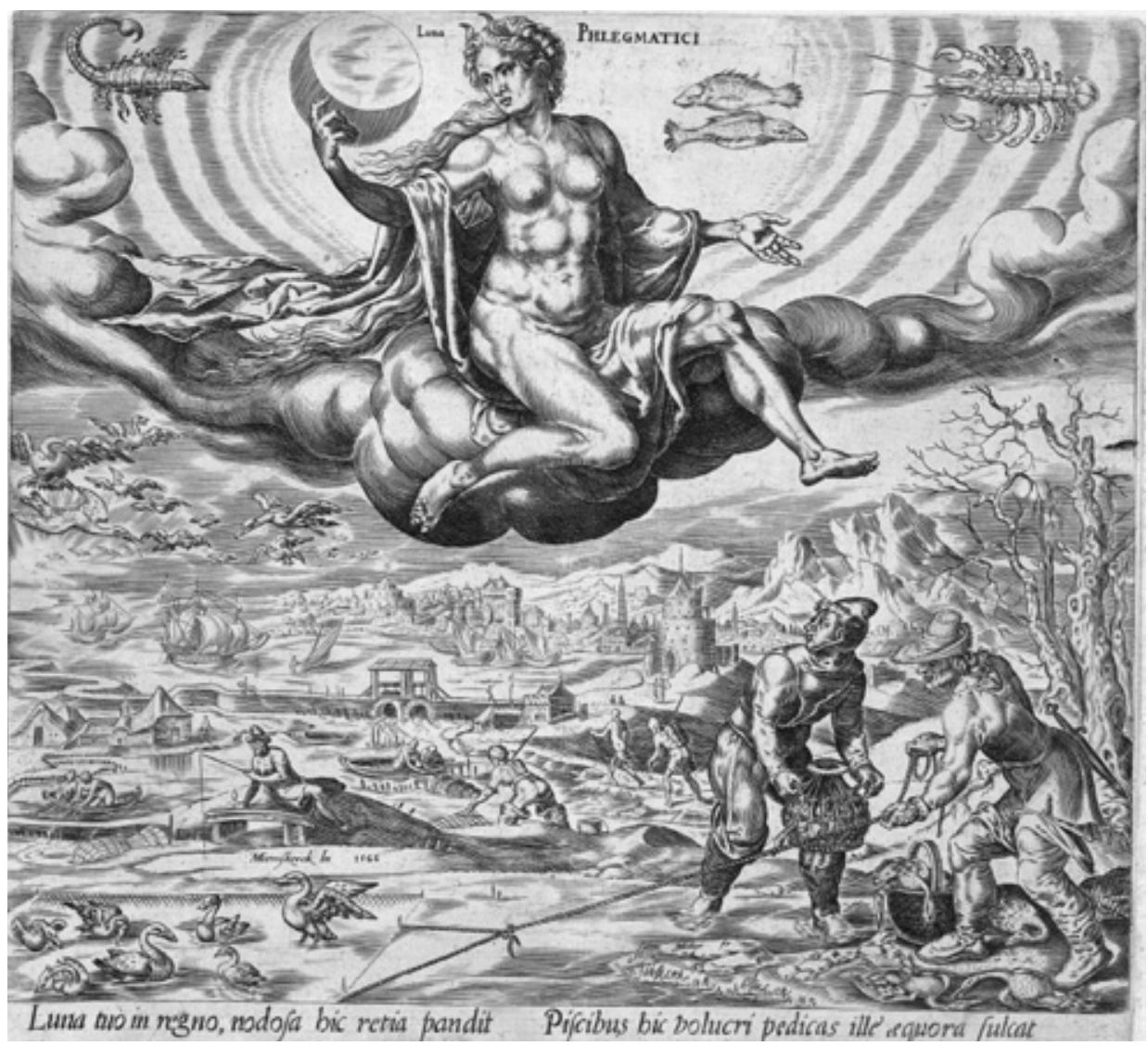

13. Flegmatycy z cyklu Quatuor praedominantes complexiones, proj. M. van Heemskerck, ryt. H. Muller, 1566 (egz. Rijksprentenkabinet, Amsterdam)

ubodzy chłopi, żebracy, kalecy i przestępcy w dybach lub szubienicznicy. $Z$ tego zestawu u Heemskercka ostał się jedynie wisielec i nieszczęśnik, który obok niego wiąże dla siebie pętlę - przy czym obaj wyglądają na samobójców, a nie na złodziei karanych szubienica. Zgodnie $z$ modą zapoczątkowaną miedziorytem Albrechta Dürera Melencolia I haarlemski grafik jako główne zawody związane $\mathrm{z}$ temperamentem saturnijskim wyeksponował mierniczych i astronomów ${ }^{46}$, na których zwraca uwagę również subskrypcja Juniusa, do towarzystwa przydając im głupców bez krzty rozumu (il. 12):

\section{Mensores terrae, vates Saturnus adoptat}

Falciger, et quibus est sana nulla uncia mentis.

Ostatnia rycina ukazuje poławiaczy ptaków i ryb, mających uosabiać flegmatyków, którym patronuje rządząca pływami morskimi bogini księżyca Luna (il. 13): 
Luna tuo in regno, nodosa hic retia pandit,

Piscibus hic volucri pedicas, ille aequora sulcat.

Każda z czterech rycin ma tytuł określający kompleksję, której dotyczy: Sangvinei (Sangwinicy), Cholerici (Cholerycy), Melancholici (Melancholicy), Phlegmatici (Flegmatycy ${ }^{47}$. Ponieważ Piotrowski-Sitnianowicz nie nadał tytułów epigramatom cyklu, nazwy owe włączył w obręb przekładów, które poza tym wcale wiernie oddają brzmienie oryginalnych subskrypcji.

\section{Cztery rzeczy namocniejsze a cykl rycin Quatuor, quae in terra fortissima sunt Gerarda Groenninga $\mathrm{z}$ około 1574 roku}

Nieco odmienny charakter od wcześniej omówionych ma cykl poetycki o czterech rzeczach najmocniejszych:

\section{CZTERY RZECZY NAMOCNIEJSZE}

[1]

Prawda tak mocna, że lub Niebo minie

Z Ziemią, a ona na wieki nie zginie;

Żywot, Ozdoba, Honor jej hołduje,

Wszytkim kierując, sama tryumfuje.

[2]

Dyjone, matka zuchwałej Wenery,

Jak strzałą razi swej gładkością cery.

Wiesz: Apomene króla w gębę biła -

Czegóż nie może wżdy niewieścia siła.

[3]

Co się na ziemi i morzu znajduje,

Wszytko człowieczej zwierzchności hołduje,

A człowiek jeszcze ma nad sobą krola -

Taka jest Boża i słuszności wola.

[4]

Kto bez żelaza wszytek świat zwojował, Rad bym od ciebie dziś się informował.

Bakchus, bo rozum, statek odymuje,

W bestyją człeka winem przenicuje ${ }^{48}$.

Rosyjscy wydawcy nie umieli wyjaśnić, skąd wywodzi się zestawienie prawdy, kobiety, władcy i wina jako czterech rzeczy najmocniejszych ${ }^{49}$. Tymczasem popularności tego tematu literackiego dowodzi już choćby wydana w 1613 roku fraszka

Zob. Maarten van Heemskerck, s. 218-221: nry 542-545. - Veldman: Seasons, Planets and Temperaments in the Work of Maarten van Heemskerck, s. 169-173; Images for the Eye and Soul, s. 205-207. w. 4, koryguję milcząco za przekazem 731; w pierwszym przekazie lekcja 2, w. 2: „Jak” poprawiona tą samą ręką na: „By”; w drugim lekcja wariantowa 4, w. 1: „świat zhołdował”; por. 1990, s. 115; 2000, s. $182 ; 2014$, s. 246). 
Adama Władysławiusza Co namocniejszego, która pośrednio wskazuje również jego źródło (w. 1-9):

\author{
U króla Daryjusza trzej zacni dworzanie \\ Trafili na takowe zadane pytanie: \\ „Co jest namocniejszego pod niebem na ziemi?" \\ Pilnie to upatrują umysły swojemi. \\ Powiedział jeden wino, a drugi zaś krola, \\ Trzeci niewiastę, jednak to chciał przydać zgoła, \\ Że prawda namocniejsza, bo wszytko zwycięża. \\ Na to przypadł i król sam, ba, i jego księża, \\ Tego za namędrszego mając dworzanina ${ }^{50}$.
}

Wspomniany tu władca to król perski Dariusz Wielki (ok. 550-485 p.n.e.), a przypowieść, do której odwołują się obaj autorzy, pochodzi z Trzeciej Księgi Ezdrasza. W roku 1566 uznano ja za apokryf i wyłączono z katolickiego oraz protestanckiego kanonu (jako kanoniczna pozostawiono tylko w prawosławnej wersji Pisma Świętego). Oficjalny status księgi nie przeszkadzał jednak, by dalej była ona uwzględniana w przekładach Biblii. Jakub Wujek, idąc za autorytetem Klementyńskiej wersji Wulgaty, tłumaczeniem apokryficznej Modlitwy Manassesa oraz Trzeciej i Czwartej Księgi Ezdrasza zwieńczył Stary Testament, „aby do końca nie zginęły, ponieważ je niektórzy święci ojcowie czasem wspominają i w niektórych biblijach łacińskich, tak ręka pisanych, jako i w drukowanych, się najdują" ${ }^{2}$. Rozdziały poświęcone rozstrzygnięciu kwestii, co jest na świecie najmocniejsze, Wujek opatrzył na marginesie stosownym tytulikiem: „Komorników króla Daryjusa gadki, co jest mocniejszego: jeśli wino czy król, czy-li i niewiasta a prawda” $(3,1-4,42)$. Trzech pokojowców monarchy założyło się o to, co jest najsilniejsze. Ich propozycje rozsadzić miał Dariusz oraz jego znamienici goście z Medii i Persji. Pierwszy sługa optował za winem, drugi za królem, ostatni zaś, Izraelita Zorobabel, zaproponował dwie możliwości: „Mocniejsze są niewiasty, ale nade wszytko prawda zwycięża” $(3,12)$. Każdy z uczestników zakładu miał szansę szerzej umotywować swój wybór. Palmę pierwszeństwa bezapelacyjnie zdobyła prawda.

Atrakcyjna przypowieść cieszyła się sporym powodzeniem. Do jej popularności przyczynili się m.in. Józef Flawiusz, szczegółowo opowiadając ją w Dawnych dziejach Izraela (XI 3, 1-6), oraz kompilator zbioru Gesta Romanorum, który włączył doń okrojoną wersję wzmiankująca jedynie trzy rzeczy najmocniejsze (pominięta została prawda) ${ }^{52}$. Za Trzecia Księga Ezdrasza ze szczegółami referowali ją dawnym polskim czytelnikom zarówno autorzy duchowni (choćby jezuici Piotr Skarga czy Tomasz Młodzianowski), jak i świeccy (np. Marcin Bielski w swojej kronice) ${ }^{53}$.

51 Biblija, to jest Ksiegi Starego i Nowego Testamentu [...]. Przeł. J. W u j e k. Kraków 1599, s. 1059. Jeśli nie zaznaczono inaczej, przekład Wulgaty za tym wydaniem, które obok innych polskich Biblii posiadał w swym księgozbiorze Symeon z Połocka (zob. H i p p i s le y, Lu k'j a n o va, op. cit., s. 33). Gesta Romanorum. Historie rzymskie. Przeł. P. H e r tz. Warszawa 2001, s. 22 1, nr 258: Najsilniejsze na świecie.

53 M. Biels ki, Kronika, to jest Historia świata [...]. Kraków 1564, k. 115v-116r. - T. Mło d zi an o w s k i, Kazania i homilie na niedziele doroczne, także święta uroczystsze [...]. T. 4. Poznań 1681, 
Z kolei wśród młodzieży szkolnej popularyzowały ją takie przedstawienia, jak Prawda niestworzona: świata zbawiciel Chrystus [...] z alegorycznej Zorobabela przed Daryjuszem królem o prawdzie rezolucyi [...] piórem i rytmem komedyjnym produkowana Józefa Sebastiana Ochockiego, którą uczniowie szkoły przy kościele św. Jana w Krakowie wystawili w Niedzielę Palmową 1702 roku $^{54}$.

Przypowieść z Trzeciej Księgi Ezdrasza w XVI stuleciu była także żywą inspiracją dla dzieł graficznych, przede wszystkim niderlandzkich. Cykle ilustrujących ją czterech wizerunków rytował Philips Galle na podstawie projektu Gerarda Groeninga, Zacharias Dolendo na podstawie projektu Karela van Mandera (pierwszym wydawca tej serii był Jacob de Gheyn Starszy, kolejnym Claes Janszoon Visscher), Jan Wierix na podstawie projektu Ambrosiusa Franckena (serię pierwszy wydał Pieter Balten między 1573 a 1592 rokiem, jej wznowienie zaś - Michiel Snyders między 1611 a 1630 rokiem) oraz Pieter Perret na podstawie projektu Hendricka Withoucka (jego cykl prasowano najpewniej około 1590 roku). Fundujące je strategie ikonograficzne były zróżnicowane: $\mathrm{w}$ pierwszym $\mathrm{z}$ wymienionych cykli cztery pojęcia przedstawiono podczas tryumfu w otoczeniu stosownej świty, w drugim w postaci scenek rodzajowych, w trzecim i czwartym zaś jako wyeksponowane na piedestałach personifikacje. Także rozwiązania dotyczące łacińskich subskrypcji rycin były niejednolite: dwa pierwsze cykle opatrzono podpisami 4-wersowymi, trzeci 6-wersowymi, ostatni zaś stosownymi wersetami $z$ apokryficznej ksiegii ${ }^{55}$. Porównanie z nimi Czterech rzeczy namocniejszych Piotrowskiego-Sitnianowicza dowodzi, że młody autor spolszczał subskrypcje najstarszej $z$ wyliczonych serii.

Cykl rycin sztychowany około 1574 roku w Antwerpii przez Philipsa Gallego na podstawie projektów Groenninga przedstawiał personifikacje niesione na lektykach w otoczeniu tryumfalnych pochodów. Łacińskie subskrypcje, luźno związane $z$ apokryficznym źródłem, sygnował Victor Ghyselinck (Giselinus, 1543-1591), filolog i humanista, w latach 1564-1583 zatrudniony w oficynie Christophe'a Plantina jako korektor, który następnie objął katedrę na uczelni w Lejdzie. Po Philipsie miedziane płyty odziedziczył pierworodny syn, Theodoor, a po jego śmierci w 1633 roku wdowa po nim, Catharina $z$ domu Moretus ${ }^{56}$. Ostatecznie ich właścicielem został Jan Galle; w roku 1638 po raz kolejny prasował on ryciny

s. 334-335. - P. Skarga, Kazania sejmowe. Oprac. J. Tazbir, przy współudz. M. Ko rolki. Wyd. 3, zmien. i uzup. Wrocław 1972, s. 48.

54 Cztery rzeczy najmocniejsze zostały zaprezentowane publiczności w scenach 1-3 aktu III: „Wezwanych do rady senatorów król wesoły, chętnie przyjmując, suorum ingenia cubiculariorum nie bez ich przytomności chcąc próbować, zapieczętowane pierwszego zdanie na trutynę podaje, gdzie zaraz autor sentymentu swego abdita eksplikuje, dowodząc, że wino jest rzecz na świecie po Bogu najpotężniejsza. Następuje drugi dworzanin, którego także zdanie pieczęcią przyciśnione król senatowi oddawszy, tłumaczyć każe, gdzie gdy króla po Bogu najpotężniejszym czyni, różnemi tego racyjami dowodzić musi. Trzeciego dworzanina sentencyją senat czyta, który gdy pisze, że niewiasta i prawda jest najpotężniejsza, kolegowie jego lichym to konceptem nazywając, z niego się naśmiewaja, ale gdy to subtelnemi dokumentami utwierdza, senat za najmędrsze zdanie jego poczyta” (J. S. O c h o c ki, Prawda niestworzona: świata zbawiciel Chrystus [...]. [Kraków 1702], s. [4-5]). Monograficzne opracowanie tematu w grafice i sztuce niderlandzkiej oraz niemieckiej dała I. M. Veld m a (Who is the strongest? The riddle of Esdras in Netherlandish art. „Simiolus” 1987, $\mathrm{nr}$ 4).

Zestaw płyt odnotowany został w inwentarzu sporządzonym po śmierci Cathariny w 1636 r.: „De 
w Antwerpii, własną sygnaturą: „Ioan. Galle excudit”, zastępując podpis poprzednika: „PGalle ex[c]udebat”. Przy tej okazji nadał tytuły zarówno poszczególnym przedstawieniom, jak i całemu cyklowi: Quatuor, quae in terra fortissima sunt, a także ponumerował ryciny, jednak nie znając źródła literackiego, pomylił ich kolejność. Symeon z Połocka korzystał z tej edycji cyklu, czego dowodzi zarówno powtórzenie owego błędu, jak i spolszczenie nowo nadanego tytułu.

Pierwsza rycina wersji z 1638 roku ukazuje potęge upersonifikowanej Prawdy (Fortitudo Veritatis). Towarzyszy jej następujacca inskrypcja Giselinusa:

\section{At Verum et Veri virtus de nomine dicta, \\ E Patris aetherei prodita Diva sinu, \\ Lux orbi irradians, nullo violabilis aevo, \\ Omnia sola regit: omnia sola potest.}

Parafraza Piotrowskiego-Sitnianowicza również eksponowała potęgę i ponadczasowość tytułowego pojęcia, jednak bardziej niż na łacińskim podpisie skupiła się na rycinie przedstawiającej niesioną na ramionach Męstwa (Fortitudo) i Wieczności (Aeternitas) lektykę Prawdy. Przed nią w modlitewnych pozach klęczą, przywołane na początku polskojęzycznej wersji, upostaciowane Niebo (Caelum) i Ziemia (Terra), za nią zaś podążają personifikacje Życia (Vita), Chwały (Splendor) i Honoru (Honor) - również wspomniane przez tłumacza: „Żywot, Ozdoba, Honor jej hołduje”.

Rycinie, która w wydaniu z 1638 roku ukazuje potęgę kobiety (Fortitudo mulieris), towarzyszy poetycki podpis:

\section{Aspicis ut blando Puero comitata Dione Rideat, illicibus lene tuens oculis. Quisquis es hinc oculos, animi si vulnera vitas, Averte, haec solo lumine cuncta domat.}

I w tym przypadku spolszczenie inspirowane było elementami przedstawienia graficznego. Nagiej Wenerze - którą, zgodnie z tradycją antyczną, znaną choćby z Owidiuszowych Amores (I 14, w. 33) czy Fasti (I, w. 461), erudyta Ghyselinck w subskrypcji określił imieniem jej matki, Dione, czego autor spolszczenia nie wychwycił, dając własne wyjaśnienie: „Dyjone, matka zuchwałej Wenery” - asystuje na rycinie Kupidyn $z$ łukiem, jednak to ona trzyma strzałę, do której nawiązał porównaniem Piotrowski-Sitnianowicz. Spośród personifikacji towarzyszących lektyce bogini miłości (Natura, Rozkosz, Kradzież) młodego poetę zainteresowała wyłącznie para stojąca na przedzie pochodu: dzierżący berło władca (Rex) i niewiasta jedną ręką przymierzająca jego koronę, drugą zaś uderzająca króla po twarzy. Źródłem tej sceny był wywód Zorobabela na temat wyższości kobiet nad władca, którego jako najmocniejszego zaproponował jego poprzednik (3 Ezd 4, 28-32):

Izali król nie jest wielki w mocy swej, którego wszytki ziemie obawiają się dotknąć? A wżdym go ja widział samego, a Apamenę, [...] założnicę jego, gdy siedziała po prawej ręce jego, a zjąwszy koronę z głowy królewskiej, włożyła ją na się i biła króla lewą ręką. Wszakoż on wtenczas zapatrzał się na nię, usta otworzywszy, a jeśliż ona piękną postawkę ukazała, tedy się jej uśmiechał, a gdy się gniewała, tedy

Vier Stercke" vier platen” (Antverpse kunstinventarissen uit de zeventiende eeuw. Uitg. E. D u v e rger. T. 4: 1636-1642. Brussels 1989, s. 18). 


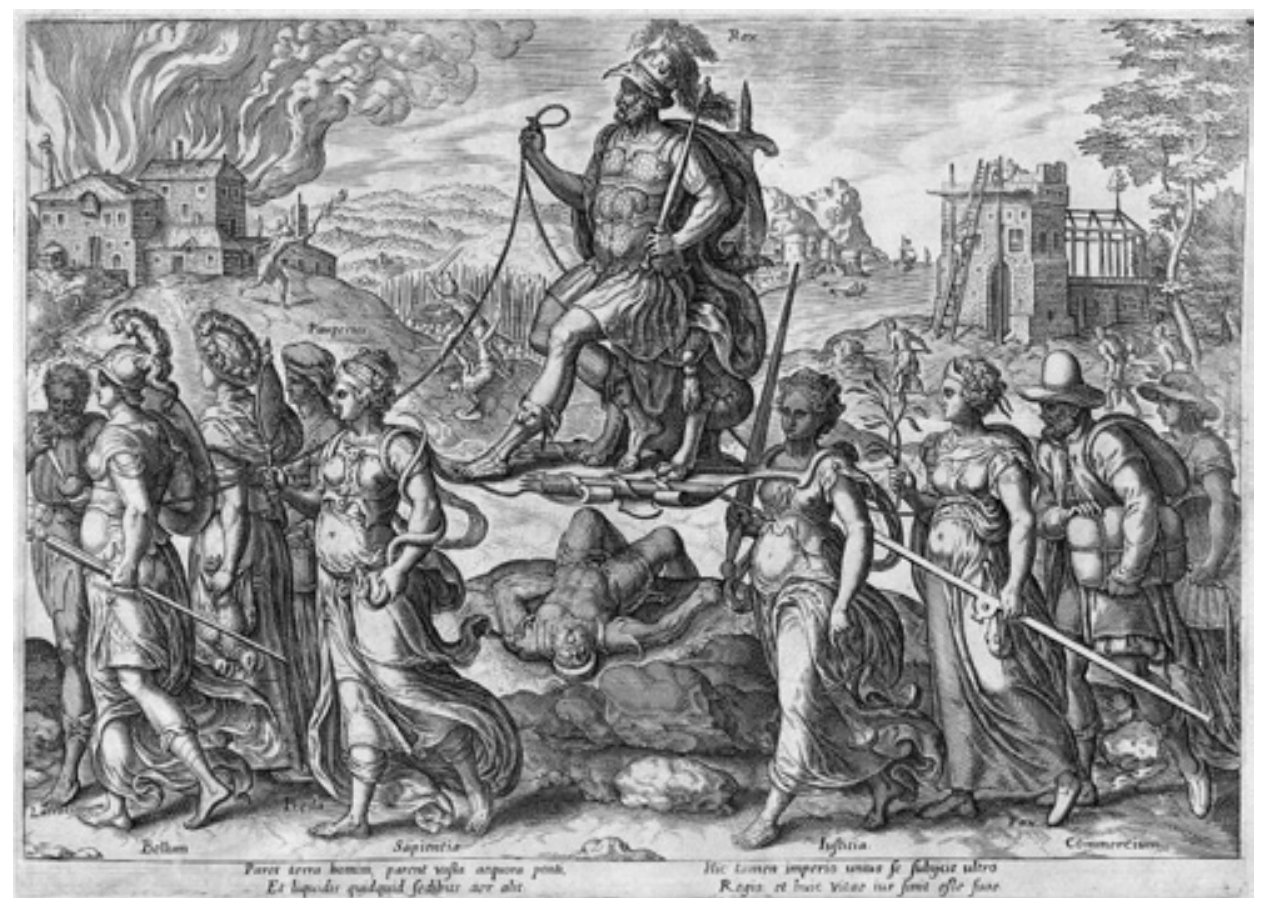

14. Potęga króla z cyklu Quatuor, quae in terra fortissima sunt, proj. G. Groenning, ryt. Ph. Galle, ok. 1574 (pierwodruk, egz. Rijksprentenkabinet, Amsterdam)

ją przepraszał, jednając się z nią. A tak, panowie moi, izaż co jest mocniejszego nad niewiasty, które takowe rzeczy przewodzą? ${ }^{57}$

Epizod z hożą Apomene (Apame) działała na wyobraźnię nowożytnych odbiorców niemal równie silnie, jak obraz Filis ujeżdżającej Arystotelesa - jedno z najpopularniejszych średniowiecznych przedstawień pożądliwej namiętności tryumfującej nad rozumem ${ }^{58}$. Kiedy w 1614 roku Goltzius namalował scenę symultanicznie ukazującą cztery największe potęgi wymienione w księdze Ezdrasza, w centrum umieścił władcę policzkowanego przez nagą metresę przymierzająca jego koronę (Apame przywłaszcza królewska koronę, albo Cztery rzeczy najmocniejsze, Musée

Ustęp wyjątkowo cytuję za Biblia brzeska (Biblija święta, to jest Księgi Starego i Nowego Zakonu właśnie z żydowskiego, greckiego i łacińskiego nowo na polskijęzyk z pilnością i wiernie wyłożone. Brześć Litewski 1563, k. 483v), której tekst jest w tym przypadku dla dzisiejszego czytelnika bardziej zrozumiały niż przekład Wujka.

58 P. Skarga (Kazania przygodne z inemi drobniejszemi pracami o różnych rzeczach wszelakim stanom należących. Kraków 1610, s. 232) np. następująco skomentował przytoczone w kazaniu wersety 3 Ezd 4, 29-31: „Tak cielesność, gdy górę weźmie, rozkazuje rozumnej duszy i koronę posłuszeństwa, które oddawać była sumnieniu winna, sama na się bierze. I rządzi sługa, i rozkazuje, co chce, panu swemu, a pan jako głupiec słucha i ugadza, i stan swój lżąc, czyni, co niegodny i niższy każe [...]. Ona go niewiasta cielesności wojuje i na nim jeździ, a on, jako osieł i wół, i szkapa, idzie, gdzie każą, i żaden mu grzech i niezbożność nietrudna”. 


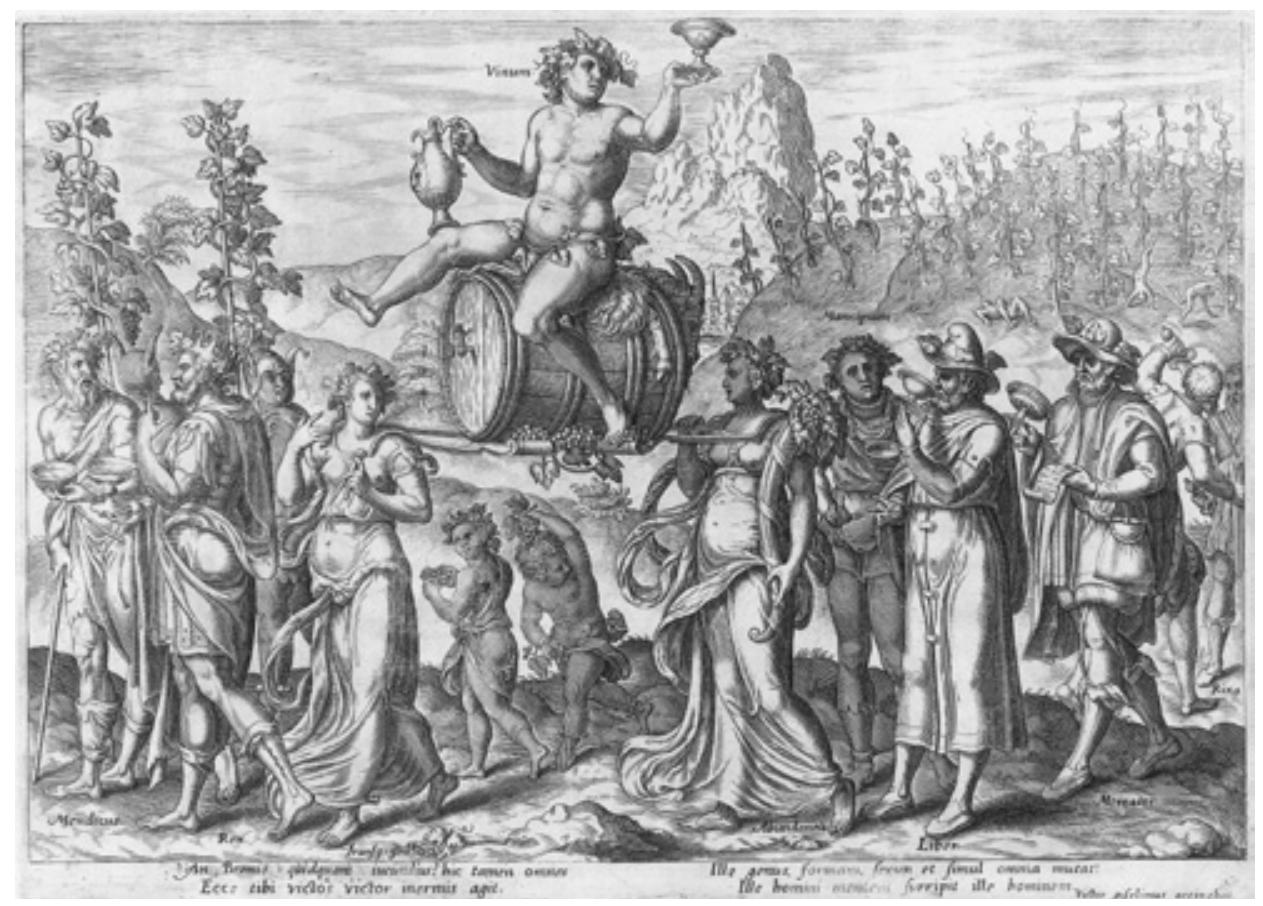

15. Potęga wina z cyklu Quatuor, quae in terra fortissima sunt, proj. G. Groenning, ryt. Ph. Galle, ok. 1574 (egz. Rijksprentenkabinet, Amsterdam)

des Beaux-Arts w Verviers ${ }^{59}$. Nic dziwnego, że przykuła ona także uwagę autora spolszczenia.

Trzecia rycina wznowienia przedstawia potęgę władcy (Fortitudo regis, il. 14):

Paret terra homini, parent vasta aequora ponti, Et liquidis quidquid sedibus aer alit.

Hic tamen imperio unius se subiicit ultro

Regis et huic vitae ius sinit esse suae.

Tym razem polska adaptacja epigramatu skupiła się wyłącznie na odzwierciedleniu sensu oryginału łacińskiego. Przekład zdaje się również uwzględniać stosowne wersety apokryficznego źródła (3 Ezd 4, 2-3):

Aza nie mocniejszy są ludzie, którzy morzem i ziemią władną i wszytkim, co na nich jest? A król wszytko przewyższa i panuje nad nimi, i wszytko, cokolwiek im rozkaże, czyni.

Także ostatni epigramat polskiego cyklu stosunkowo wiernie przekazuje sens subskrypcji Ghyselincka do ryciny przedstawiającej potęgę wina (Fortitudo vini, il. 15): 
Ille genus, formam, sexum et simul omnia mutat: Ille homini mentem surripit ille hominem ${ }^{60}$.

$Z$ dwóch argumentów oryginału na rzecz potęgi wina - zmienia ono stan społeczny, wygląd i płeć pijanych oraz pozbawia ich człowieczeństwa - wileński student skupił się na drugim, bagatelizując złożony program ikonograficzny ryciny.

\begin{abstract}
RADOSŁAW GRZEŚKOWIAK University of Gdańsk

ORCID: 0000-0002-6160-9982

\section{POEMS ON DRAWINGS AS A DOMINANT OF SYMEON OF POLOCK'S POLISH OUTPUT} PART 2: FOURFOLDS

The article is a continuation of the paper published in "Literary Memoir" 2017, issue 3, devoted to the graphic sources of Polish epigrammatic cycles by Samuił Gawryłowicz Piotrowski-Sitnianowicz (16291680), later known under the assumed monastic name of Symeon of Połock. Studying between the years 1650-1653 at the Vilnius Academy, the young poet composed epigrammatic cycles to almost 30 series of Netherlandic drawings. The present article discusses the poet's following cycles: Cztery świata wieki (Four Centuries of the World), an adaptation of Tobias Verhaecht's drawing series Quatuor mundi aetates from before the year 1599, Cztery części roku pogody (Four Parts of the Year's Weather), which is an adaptation of a series of Maarten van Heemskerck's 1563 drawings entitled Quatuor anni tempestates, Cztery części dnia (Four Parts of a Day), being an adaptation of Verhaecht's drawing series Quatuor temporis partes et intervalla, Cztery żywioły i skutki onych (The Four Elements and Their Effects) adapting Maarten de Vos' Quatuor elementa, eorumque effectus from circa the year 1582, Cztery przemagajace kompleksyje (Four Predominating Complexities) which is an adaptation of Heemskerck's 1566 series of drawings Quatuor praedominantes complexiones, and the cycle Cztery rzeczy namocniejsze (Four Strongest Things) referring to a story from an apocryphal account of 3 Ezdras (3, 1-4, 42), and being an adaptation of Gerard Groenning's series of drawings from circa the year 1574.
\end{abstract}

60 Zob. Philips Galle. Comp. M. Sellin k, M. Le e s berg. Ed. M. Sellink. Rotterdam 2001. T. 2, s. 211-216: $n$ r 273-276. 